\title{
A metal-free salalen ligand with anti-tumor and synergistic activity in resistant leukemia and solid tumor cells via mitochondrial pathway
}

\author{
Sina M. Hopff ${ }^{1}\left[\right.$ - Qifang Wang ${ }^{2} \cdot$ Corazon Frias $^{1} \cdot$ Marie Ahrweiler $^{1} \cdot$ Nicola Wilke $^{1} \cdot$ Nathalie Wilke $^{1}$. \\ Albrecht Berkessel ${ }^{2} \cdot$ Aram Prokop $^{1,3,4}$
}

Received: 3 December 2020 / Accepted: 27 May 2021 / Published online: 2 July 2021

(c) The Author(s) 2021

\begin{abstract}
Purpose Since the discovery of the well-known cis-platin, transition metal complexes are highly recognized as cytostatic agents. However, toxic side effects of the metal ions present in the complexes may pose significant problems for their future development. Therefore, we investigated the metal-free salalen ligand WQF 044.

Methods DNA fragmentations in leukemia (Nalm6) and solid tumor cells (BJAB, MelHO, MCF-7, RM82) proved the apoptotic effects of WQF 044, its overcoming of resistances and the cellular pathways that are affected by the substance. The apoptotic mechanisms finding were supported by western blot analysis, measurement of the mitochondrial membrane potential and polymerase chain reactions.

Results A complex intervention in the mitochondrial pathway of apoptosis with a Bcl-2 and caspase dependence was observed. Additionally, a wide range of tumors were affected by the ligand in a low micromolar range in-vitro. The compound overcame multidrug resistances in P-gp over-expressed acute lymphoblastic leukemia and CD95-downregulated Ewing's sarcoma cells. Quite remarkable synergistic effects with vincristine were observed in Burkitt-like lymphoma cells.

Conclusion The investigation of a metal-free salalen ligand as a potential anti-cancer drug revealed in promising results for a future clinical use.
\end{abstract}

Keywords Metal-free ligand $\cdot$ Salalen $\cdot$ Mitochondrial pathway $\cdot$ Apoptosis $\cdot$ Synergistic effects $\cdot$ Multidrug resistance

\section{Introduction}

Developing new anti-cancer targets, especially against resistant tumors, is very challenging in cancer research (Kelland 2007). The discovery of the well-known cisplatin was pioneering on this field, but severe side effects limit the use

Sina M. Hopff

sina.hopff@uk-koeln.de

1 Department of Pediatric Hematology/Oncology, Municipal Clinics of Cologne, Children's Hospital of the City Cologne, Amsterdamer Straße 59, 50735 Cologne, Germany

2 Department of Chemistry, University of Cologne, Greinstraße 4, 50939 Cologne, Germany

3 Department of Pediatric Hematology/Oncology, Helios Clinic Schwerin, Wismarsche Straße 393-397, 19055 Schwerin, Germany

4 Medical School Hamburg (MSH), University of Applied Sciences and Medical University, Am Kaiserkai 1, 20457 Hamburg, Germany of platin derivates (Bruijnincx and Sadler 2008; Kelland 2007; Rabik and Dolan 2007; Wild2012). Therefore finding new substances without a metal ion in its center is of high interest.

Salans, salalens and in particular salens are most prominent ligands in coordination chemistry, and many of their metal complexes have shown potent antitumor activity (Scheme 1, top) (Grutzke et al. 2015; Hopff et al. 2020; Immel et al. 2011, 2012a, b; Lee 2010, 2011; Meker et al. 2011; Mir et al. 2017; Peri et al. 2011; Terenzi 2016). However, earlier work of ours on Mo-complexes had revealed that the biological activity may actually reside in the ligand. For example, the metal-free salan ligand THG 1213 (Scheme 1, bottom right) was in fact much more active than the corresponding Mo-complexes (Dragoun et al. 2018). Another striking observation was that the corresponding salen ligand THG 1212 (Scheme 1, bottom left) was inactive (Dragoun et al. 2018).

With this in mind, we decided to also investigate the metal-free salalen ligand WQF 044 (Scheme 1, bottom 
Scheme 1 Top: General structures of the salen, the salalen, and the salan motifs. Bottom: Explicit structures of the salen THG 1212, the salalen WQF 044 (this work), and of the salan THG 1213
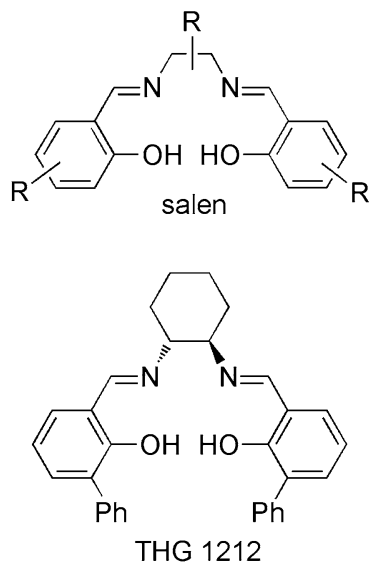

middle). The catalytic activity and characterization of the compound is already known (Berkessel et al. 2007). Please note that the salalen WQF 044 is the direct salalen analogue of the salan THG 1213 investigated earlier (Dragoun et al. 2018). Additionally, no biological data representing the apoptotic activity of salalan ligands have been published so far. We were delighted to see that the salalen WQF 044 affected leukemia, lymphoma, mamma carcinoma and melanoma cells in a low micromolar range. We extended the number of cell lines to a human Ewing's sarcoma cell line that we recently made resistant to vincristine. The main focus of interest was to find out the in-vitro cytotoxicity in resistant tumor cells and to compare the apoptotic activity of the compound with cytostatics including salans and salens that were published before. In fact, a proposal for the apoptotic mechanism of action of WQF 044 could be derived from our studies on a wide range of different tumor cells and modified cell lines.

\section{Results}

\section{Proof of anti-proliferative effects of WQF 044 and cell death via apoptosis}

The salalen ligand WQF 044 inhibits proliferation and induces apoptosis in human B cell precursor leukemia cells (Nalm6). The following microscopic photos visualize the effect of WQF 044 on the Nalm6 cells after $72 \mathrm{~h}$ of incubation. In the control (Fig. 1a), a large number of Nalm6 cells can be observed. The cells are not apoptotic as they appear clear and round. Leukemia cells that were treated with $1 \mu \mathrm{M}$ of WQF 044 are shown in Fig. 1b. Conspicuous is the lower number of cells. It is apparent that the cells look significantly damaged. They lost their circular and light appearance. Figure 1c clearly illustrates the high apoptotic effect
The salen, salalen, and salan structural motifs:
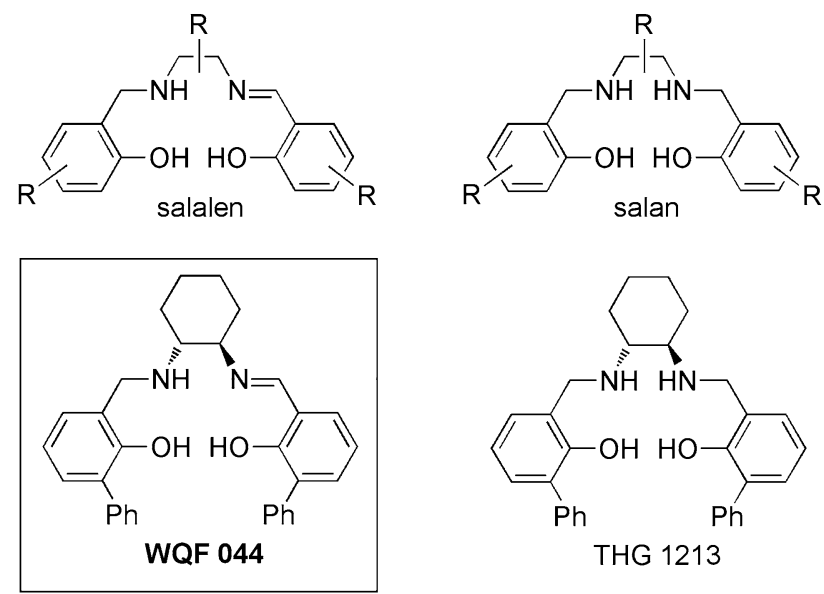

a

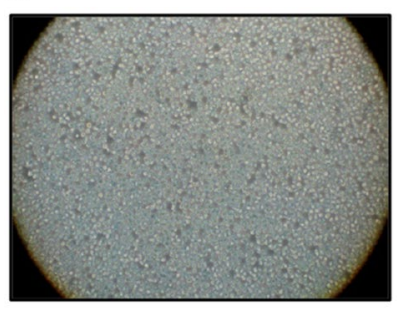

b
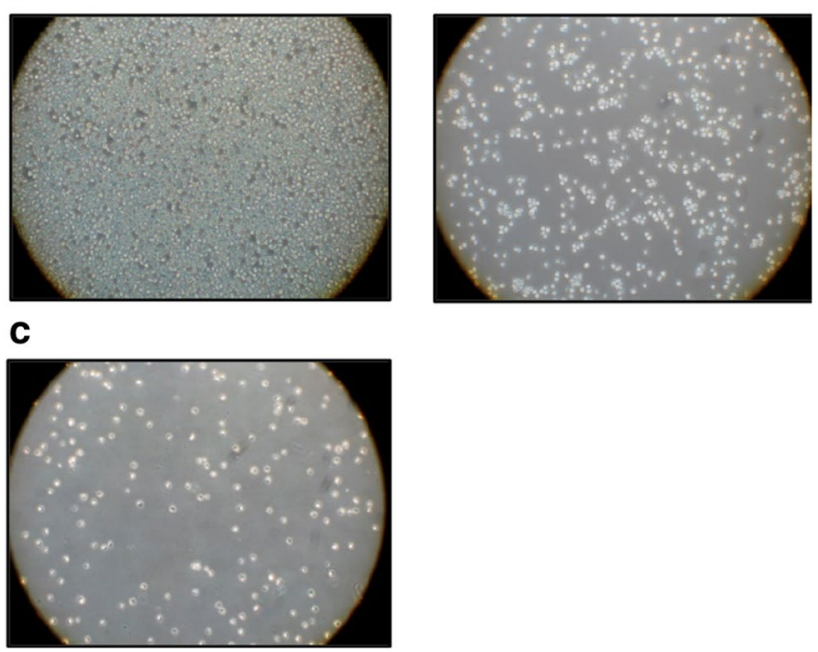

Fig. 1 a-c Morphology of Nalm6 cells under the microscope after $72 \mathrm{~h}$ of incubation at $37{ }^{\circ} \mathrm{C}$. a Control cells were left untreated. b Nalm6 cells were treated with $1 \mu \mathrm{M}$ of WQF 044 . c $10 \mu \mathrm{M}$ of WQF 044 was pipetted on these cells

on the cells after pipetting $10 \mu \mathrm{M}$ of the compound. The few cells remaining are all damaged.

The anti-proliferative potency of WQF 044 was proved by using the CASY cell counter. After pipetting $1-20 \mu \mathrm{M}$ of the substance, an inhibited proliferation of over 95 percent was observed (Fig. 2b). IC $_{50}$, the concentration of WQF 044 necessary to affect half maximal growth inhibition, is lower than $3 \mu \mathrm{M}$ in Nalm6 cells. Furthermore, it is important that the cell death, triggered by WQF 044, is due to apoptosis and not necrosis. A lactate dehydrogenase (LDH) release measurement gives information about this fact. During necrosis, the cells lose their membrane integrity so that LDH can easily migrate out of the cells. This process does not happen during apoptosis within the first hours (Van Cruchten 

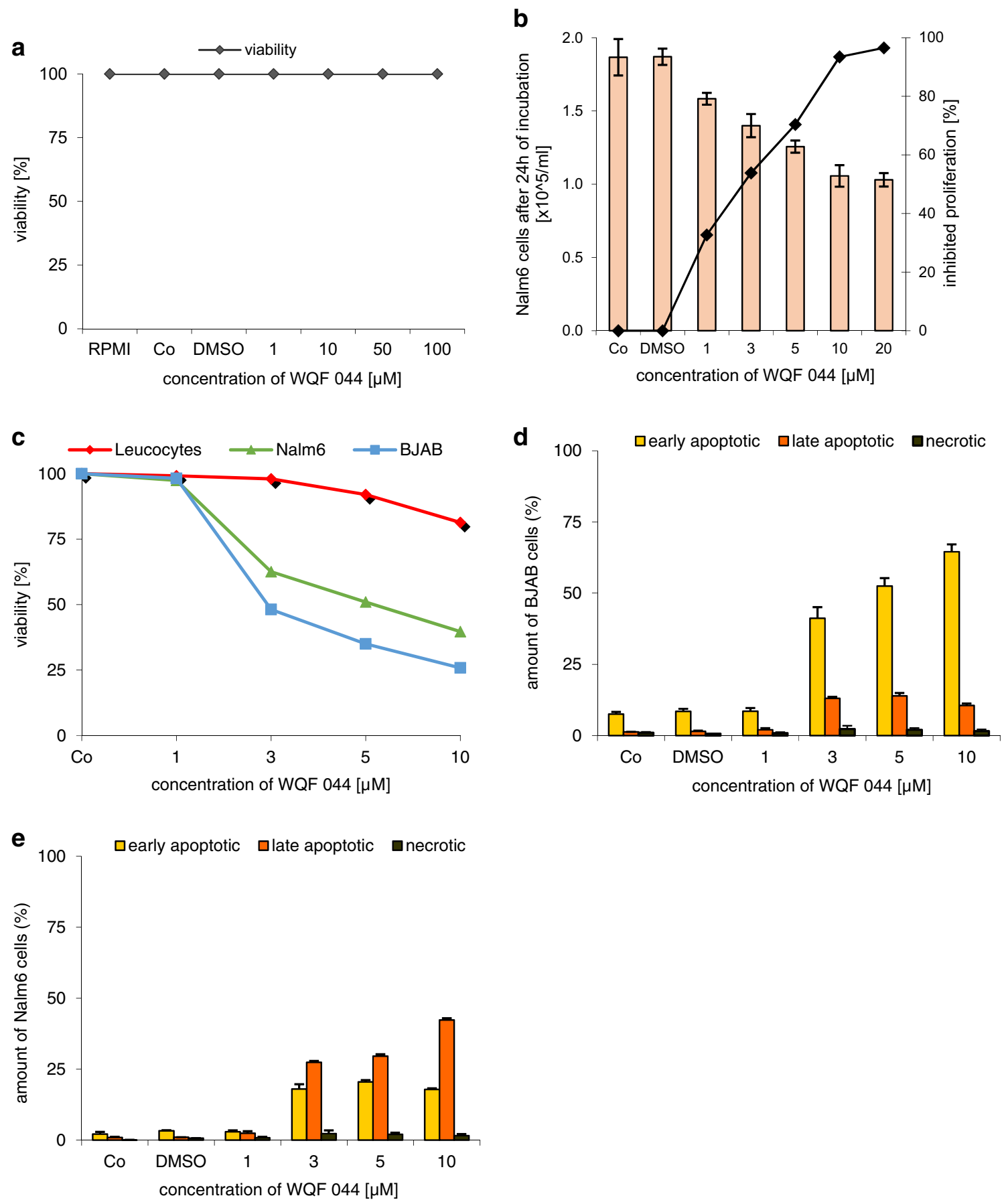

Fig. 2 Inhibition of proliferation and excluding of necrosis. a Different concentrations of WQF 044 were pipetted on Nalm6 cells. After $3 \mathrm{~h}$ of incubation at $37^{\circ} \mathrm{C}$, an $\mathrm{LDH}$ release assay was made to determine the viability. Values are given as percentage of control (Co) $(n=3)$. b Nalm6 cells were treated with different concentrations of WQF 044 and incubated for $24 \mathrm{~h}$. The CASY cell counter and analyzer system was used to measure the proliferation with three batches per concentration. The number of untreated control cells (Co) was set

as $0 \%$ growth inhibition. Values are given as percentage of inhibition of cell proliferation $(n=3)$. c-e BJAB and Nalm6 cells and leucocytes were incubated with different concentrations of WQF 044 for $48 \mathrm{~h}$. The viability, early and late apoptosis and necrosis were measured after Annexin V/PI staining by using flow cytometry. In the Annexin V/PI assay, vital cells (AnnV-/PI-) can be distinguished from early apoptotic (AnnV+/PI-), late apoptotic (AnnV+/PI+), and necrotic (AnnV-/PI+) cells. Three batches per concentration were used 
and Van Den Broeck 2002). We incubated WQF 044-treated Nalm6 cells for $3 \mathrm{~h}$ and made a LDH release assay that revealed no significant detection of LDH outside the cells (Fig. 2a) (Wieder et al. 1998). To specify the stage of apoptosis induced by WQF 044 an Annexin-V/propidium iodide (PI) assay was made. Annexin V binds to phosphatidylserine that is released in an early stage of apoptosis (Fadok et al. 2001; Schlegel and Williamson 2001). This exposure lasts until the final stage of apoptosis. PI is membrane impermeable. Therefore, cells that are devoid of PI staining show an intact membrane (van Engeland et al. 1998).

Next to the leukemic Nalm6 cells, Burkitt-like lymphoma cells (BJAB) were used for this experiment. First of all the data underlined that cell death induced by WQF 044 was due to apoptosis and not necrosis (Fig. 2d, e). After $48 \mathrm{~h}$ of incubation with WQF 044, it turned out that the highest amount of BJAB cells was in an early stage of apoptosis (Annexin V-positive, PI-negative) (Fig. 2d) whereas Nalm6 cells showed more late apoptosis after the same time (Annexin V/PI-double-positive), but still some early apoptotic cells (Fig. 2e). Furthermore, at a concentration of $10 \mu \mathrm{M}$, WQF 044 reduced the number of vital BJAB cells by approximately 75 percent and Nalm6 cells by 60 percent (Fig. 2c).

\section{WQF 044 overcomes multidrug resistance in leukemia cells}

The overcoming of multidrug resistance (MDR) is an important quality of a new substance because MDR poses a huge problem in the treatment of relapsed malignant diseases (Uderzo et al. 2001). Various cellular-based mechanisms are responsible for the development of MDR in tumor cells. The excretion of P-glycoprotein (P-gp), encoded by the MDR1/ACBC1 gene, is one of these mechanisms (Gottesman et al. 2002; Krishna and Mayer 2000; Marques 2019). It is an efflux pump in the cell membrane that transports drugs out of the cells resulting in a decrease of the cellular drug concentration (Gottesman and Pastan 1988; Lin and Yamazaki 2003; Mukhametov and Raevsky 2017). It has been proven that P-gp over-expression causes resistances to taxanes, anthracyclines and vinca-alkaloids because they are substrates of this transporter (Pieters et al. 1997; Wang et al. 2017). In our lab, we generated a vincristine resistant (NVCR) and a daunorubicin-resistant (NDau) Nalm6 cell line that are both characterized by an over-expression of P-gp (Rubbiani 2010). They are additionally resistant to fludarabine, paclitaxel and colchicine (Kater et al. 2011; Kater 2012). Only recently, we found out that NDau cells are also resistant to cytarabine, mitoxantrone, idarubicin, doxorubicin, epirubicin, etoposide and the vinca alkaloids. Except of a cytarabine sensibility, NVCR cells have the same tested co-resistances as the NDau cells (Table 1).
DNA fragmentations effected by WQF 044 in the resistant cell lines compared to the Nalm6 cell line revealed that this ligand has the potential to overcome the MDR. The apoptotic effects were even significantly higher in the resistant cell lines than in the control Nalm6 cells after exposing them to 1 to $5 \mu \mathrm{M}$ of WQF 044 (Fig. 3a, b).

\section{Bcl-2 over-expression in Burkitt-like lymphoma and human melanoma cells reduces activity of WQF 044}

Another mechanism of MDR is the over-expression of the anti-apoptotic protein Bcl-2 in tumor cells (Krishna and Mayer 2000). At this point, BJAB cells and its vincristineresistant cells $(\mathrm{BiBo})$ played a main role because the $\mathrm{BiBo}$ cells are characterized by an Bcl2-over-expression (Kater et al. 2011). The cells further have co-resistances to cytarabine, daunorubicin, vindesine, vinorelbine, vinblastine and paclitaxel (Table 1). A DNA fragmentation with WQF 044 in these two cell lines gave further information about the working mechanism of the substances. First of all, it can be said that WQF 044 induces apoptosis in BJAB cells in a dose-dependent manner (Fig. 4a). In comparison to that the apoptotic effects in BiBo cells were significantly lower than in the BJAB cells, but at least values up to 50 percent at $5 \mu \mathrm{M}$ of WQF 044 could be reached. The same phenomenon was observed in the analysis of a DNA fragmentation with special human melanoma cells (MelHO). The MelHO pIRES cell line was stably transfected with the pIRES vector. Compared to this the MelHO Bcl-2 cells had the pIRES$\mathrm{Bcl}-2$-vector included. They strongly over-express the antiapoptotic Bcl-2 protein (Jesse et al. 2009). Figure 4b clearly demonstrates that WQF 044 had no effect on the MelHO Bcl-2 cell line, but induced apoptosis in the MelHO pIRES cells with a high significance compared to the MelHO Bcl-2 cells, respectively.

\section{WQF 044 regulates mitochondria-related Bcl-2 family proteins, DIABLO and cytochrome C}

Even though a dependence of WQF 044 on the Bcl-2 overexpression can be observed, we found several gene expressions, including members of the Bcl-2 family, in a polymerase chain reaction (PCR) analysis of WQF 044 treated Nalm6 cells. The analysis revealed a downregulation of the anti-apoptotic Bcl-2 by 18 -fold and a 5-times upregulation of the $\mathrm{Bcl}-2$-associated $\mathrm{X}$ protein (BAX) that is pro-apoptotic (Table 2) (Edlich 2018; Garner et al. 2017). Thus, we assume that WQF 044 has an influence on Bcl-2 even though higher concentrations are needed to reach apoptotic effects.

The PCR array analysis also produced other gene expressions that lead to the pathway in which WQF 044 intervened. An over-expression of the IAP-binding mitochondrial 
Table 1 Co-Resistances of different tumor cell lines

\begin{tabular}{|c|c|c|c|c|c|}
\hline & NVCR & NDau & BiBo & 7CCA & RM82SiHoVCR \\
\hline Cytarabine & $\mathrm{S}$ & $\mathrm{R}$ & $\mathrm{R}$ & $\mathrm{R}$ & $\mathrm{R}$ \\
\hline Fludarabine & $\mathrm{R}$ & $\mathrm{R}$ & $\mathrm{S}$ & $\mathrm{R}$ & $\mathrm{S}$ \\
\hline Cladribine & $\mathrm{S}$ & $S$ & $\mathrm{~S}$ & $\mathrm{R}$ & $\mathrm{S}$ \\
\hline Clofarabine & $\mathrm{S}$ & $S$ & $\mathrm{~S}$ & $\mathrm{R}$ & $\mathrm{S}$ \\
\hline Mitoxantrone & $\mathrm{R}$ & $\mathrm{R}$ & I & $\mathrm{R}$ & $\mathrm{R}$ \\
\hline Idarubicin & $\mathrm{R}$ & $\mathrm{R}$ & $\mathrm{S}$ & $\mathrm{R}$ & $\mathrm{S}$ \\
\hline Daunorubicin & $\mathrm{R}$ & $\mathbf{R}$ & $\mathrm{R}$ & $\mathrm{R}$ & $\mathrm{R}$ \\
\hline Doxorubicin & $\mathrm{R}$ & $\mathrm{R}$ & $\mathrm{S}$ & $\mathbf{R}$ & $\mathrm{R}$ \\
\hline Epirubicin & $\mathrm{R}$ & $\mathrm{R}$ & I & $\mathrm{R}$ & $\mathrm{R}$ \\
\hline Etoposide & $\mathrm{R}$ & $\mathrm{R}$ & $\mathrm{S}$ & $\mathrm{R}$ & I \\
\hline 4-OH-Cyclophosphamide & $\mathrm{S}$ & $S$ & $\mathrm{~S}$ & $\mathrm{R}$ & $\mathrm{S}$ \\
\hline Methotrexate & $\mathrm{S}$ & $S$ & $\mathrm{~S}$ & $\mathrm{~S}$ & $\mathrm{~S}$ \\
\hline Vindesine & $\mathrm{R}$ & $\mathrm{R}$ & $\mathrm{R}$ & $\mathrm{R}$ & $\mathrm{R}$ \\
\hline Vinorelbine & $\mathrm{R}$ & $\mathrm{R}$ & $\mathrm{R}$ & $\mathrm{R}$ & $\mathrm{R}$ \\
\hline Paclitaxel & $\mathrm{R}$ & $\mathrm{R}$ & $\mathrm{R}$ & $\mathrm{R}$ & $\mathrm{R}$ \\
\hline Vinblastine & $\mathrm{R}$ & $\mathrm{R}$ & $\mathrm{R}$ & $\mathrm{R}$ & $\mathrm{R}$ \\
\hline Vincristine & $\mathbf{R}$ & $\mathrm{R}$ & $\mathbf{R}$ & $\mathrm{R}$ & $\mathbf{R}$ \\
\hline Fluoruracil & $\mathrm{S}$ & $\mathrm{S}$ & $\mathrm{S}$ & $\mathrm{S}$ & I \\
\hline Resistant mechanisms & $\begin{array}{l}\text { P-gp over- } \\
\text { expres- } \\
\text { sion }\end{array}$ & $\begin{array}{l}\text { P-gp over- } \\
\text { expres- } \\
\text { sion }\end{array}$ & $\begin{array}{l}\text { Bcl-2 over- } \\
\text { expres- } \\
\text { sion }\end{array}$ & $\begin{array}{l}\text { Caspase-3 } \\
\text { under- } \\
\text { expression }\end{array}$ & $\begin{array}{l}\text { CD95 under-expression, } \\
\text { caspase-8 downregula- } \\
\text { tion }\end{array}$ \\
\hline
\end{tabular}

DNA-fragmentation was measured as described with the wild-type cell lines and its resistant cell line. The written cytostatics were pipetted on the cells in different concentrations $(n=3)$. Apoptotic effects were compared. Cells were resistant $(\mathrm{R})$ if the apoptotic effect in the resistant cell line was half times lower than in the main cell line in a dose-dependent manner. Intermediate (I) stadium was chosen if apoptosis was significantly lower in the resistant cell line, but still higher than the half-value of the non-resistant cell line. Otherwise the cells were sensible (S) to the cytostatic. The primary resistant mechanisms of the cell lines are written with an $\mathrm{R}$ in bold

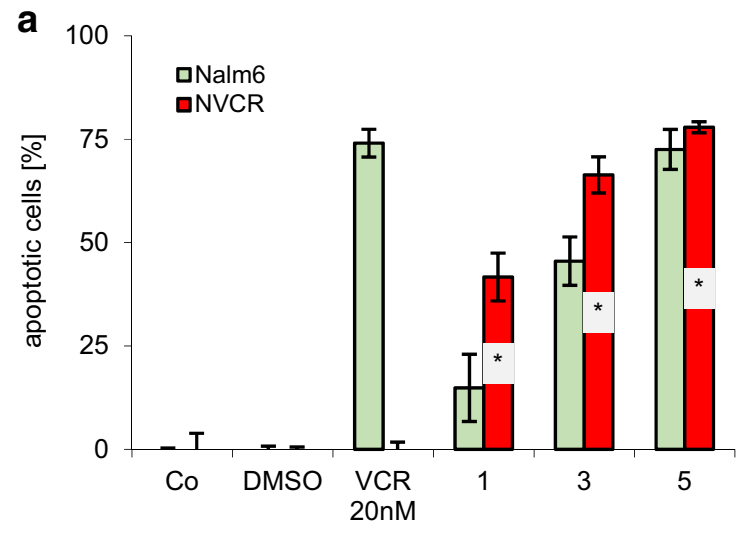

concentration of WQF $044[\mu \mathrm{M}]$

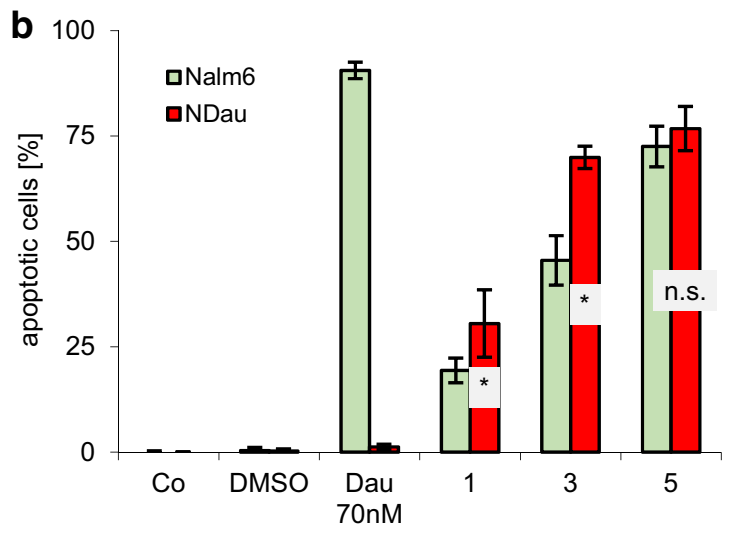

concentration of WQF $044[\mu \mathrm{M}]$
Fig. 3 Overcoming of MDR is proved by treating resistant cells and control Nalm6 cells with different concentrations of WQF 044. Untreated cells were left as control (Co). Incubation time was $72 \mathrm{~h}$ at $37{ }^{\circ} \mathrm{C}$. DNA fragmentation was measured by flow cytometric analysis. Values are given in percent $\pm \mathrm{SD}(n=3)$. a DNA fragmentation of Nalm6 cells was compared with vincristine-resistant Nalm6 cells

protein (DIABLO) and cyctochrom c, somatic (CYCS) was observed (Table 2). These proteins, including Bcl-2 family
(NVCR). To prove the resistance, both cell lines were treated with vincristine (VCR). b The experiment was repeated with Nalm6 cells and daunorubicin-resistant NDau cells and resistance is shown by comparing the apoptotic effects in daunorubicin (Dau) treated cells. Comparison of data was calculated by a one-tail $t$ test: $* p<0.05$; $n s$ not significant

members, are part of the intrinsic apoptotic pathway that is mitochondria-dependent (Won 2018). However, apoptosis 


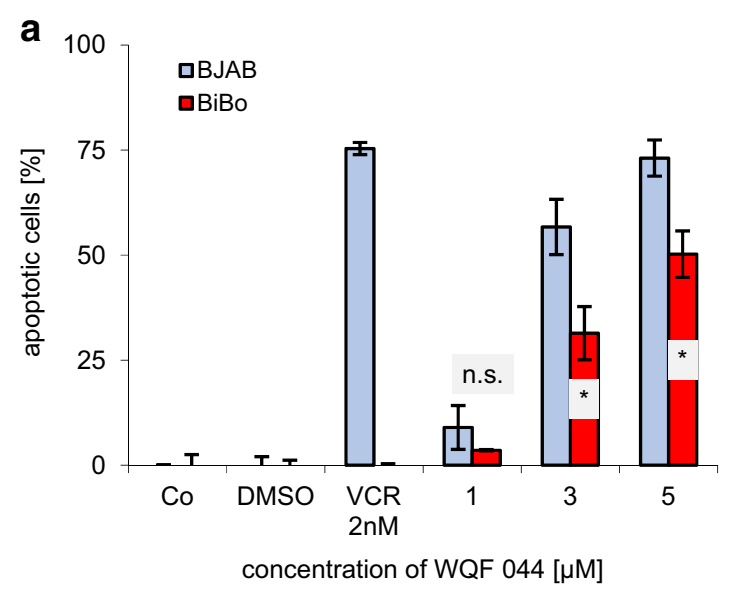

Fig. 4 Dependence of a Bcl-2 over-expression in vincristine-resistant BiBo cells and pIRES-Bcl-2-vector transfected MelHO cells. After $72 \mathrm{~h}$ of incubating the cells at $37^{\circ} \mathrm{C}$, DNA fragmentation was measured by flow cytometric analysis. Control cells were left untreated (Co). Apoptotic cells were displayed as percentage of the means of three separate samples \pm SD. Comparison of data was calculated by a one-tail t-test. Results have been asterisked as follows: $* p<0.05$;

Table 2 PCR analysis of WQF 044 treated Nalm6 cells

\begin{tabular}{lcc}
\hline $\begin{array}{l}\text { Genes over-/under- } \\
\text { expressed }\end{array}$ & Fold-change & Fold-regulation \\
\hline Bcl-2 & 0.0545 & -18.3537 \\
BAX & 4.6332 & 4.6332 \\
CD95 & 0.0236 & -42.459 \\
Cytochrome C & 42.5769 & 42.5769 \\
DIABLO & 15.9115 & 15.9115 \\
FADD & 0.1758 & -5.6883 \\
\hline
\end{tabular}

WQF 044 treated Nalm6 cells were incubated for $16 \mathrm{~h}$ at $37^{\circ} \mathrm{C}$. For PCR analysis the apoptosis-specific RT2 profiler PCR expression array (SuperArray PAHS-012Z; SABiosciences Corporation, Frederick, MD, USA) was used. Fold-Change $\left(2^{\wedge}(-\Delta \Delta \mathrm{Ct})\right)$ is the normalized gene expression $\left(2^{\wedge}(-\Delta \mathrm{Ct})\right)$ in the Test Sample (WQF 044 treated Nalm6 cells) divided the normalized gene expression $\left(2^{\wedge}(-\right.$ $\Delta \mathrm{Ct})$ ) in the Control Sample (untreated Nalm6 cells). Fold-Regulation represents fold-change results in a biologically meaningful way. Fold-change values greater than one indicate a positive- or an upregulation, and the fold-regulation is equal to the fold-change. Foldchange values less than one indicate a negative or down-regulation, and the fold-regulation is the negative inverse of the fold-change

can also be triggered by the death receptor-dependent extrinsic pathway (Nair et al. 2014).

\section{The mitochondrial membrane potential is reduced by WQF 044}

The activation of the intrinsic pathway results in a loss of the mitochondrial membrane potential (Lambert et al. 1989). To investigate the influence of WQF 044 on the mitochondrial

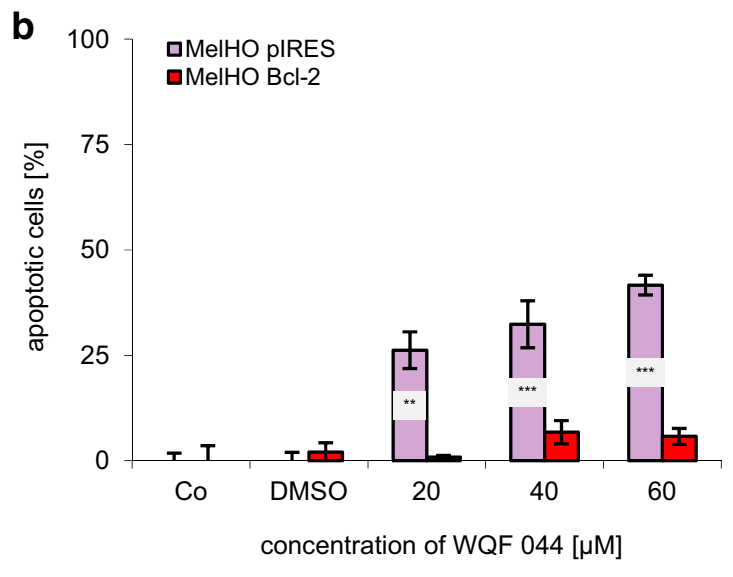

${ }^{* *} p<0.01 ; * * * p<0.001 ; n s$ not significant. a BJAB and BiBo cells were treated with different concentrations of WQF 044. Additionally, both cell lines were treated with vincristine (VCR) to prove the resistance. b WQF 044 was pipetted on MelHO pIRES und MelHO Bcl-2 cells in three different concentrations. Higher concentrations than in Nalm6 and BJAB cells were used due to the lower sensitivity of these adherent cells

permeability transition that can already be seen in the results of the PCR array analysis, Nalm6 cells were stained with a JC-1 dye. Flow cytometric determination showed a decreased fluorescence of Nalm6 cells, reflecting mitochondrial permeability. Figure 5a clearly illustrates the loss of mitochondrial membrane depolarization, beginning from $3 \mu \mathrm{M}$ of WQF 044 .

\section{Caspase-dependence of WQF 044}

The protease caspase- 3 is a key component of the apoptotic pathway. During apoptosis, it is taking part in the proteolytic cleavage of many key proteins (Cohen 1997). To investigate whether WQF 044 develops its apoptotic effects via an activation of caspase-3, we tested the substance on special cell lines. One cell line is the doxorubicin-resistant BJAB cell line (7CCA) that is characterized by a caspase- 3 underexpression (Dragoun et al. 2018). Multiple co-resistances of 7CCA were found to cytarabine, fludarabine, cladribine, clofarabine, mitoxantrone, idarubicin, daunorubicin, epirubicin, etoposide, 4-OH-cyclophosphamide, vindesine, vinorelbine, paclitaxel, vinblastine and vincristine (Table 1). Figure 5c clearly illustrates that WQF 044 could not affect the 7CCA cells, whereas the regular BJAB cells were highly apoptotic at WQF 044 concentrations of 3 to $5 \mu \mathrm{M}$.

To further support that WQF 044 is dependent of caspase-3, we used the human breast adenocarcinoma cell line MCF-7/mock and its modified cells called MCF-7/casp-3. It is known that MCF-7/mock cells lack the enzyme caspase-3 (Engels et al. 2005). The second one has caspase-3 later incorporated in the cells so that they stably express this 

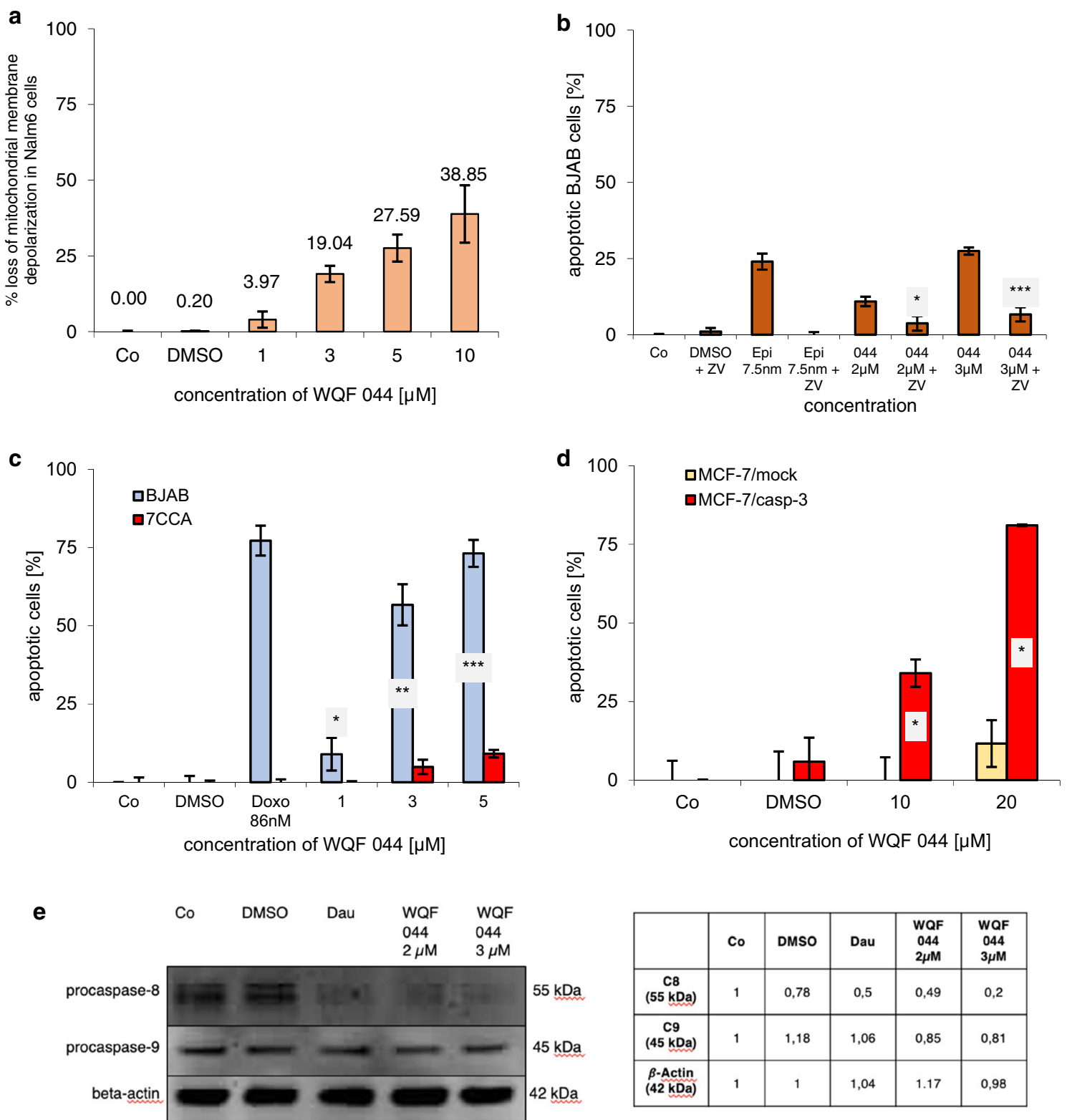

\begin{tabular}{|c|c|c|c|c|c|}
\hline & Co & DMSO & Dau & $\begin{array}{c}\text { WQF } \\
\mathbf{0 4 4} \\
\mathbf{2 \mu M}\end{array}$ & $\begin{array}{c}\text { WQF } \\
\mathbf{0 4 4} \\
\mathbf{3} \mu \mathrm{M}\end{array}$ \\
\hline $\begin{array}{c}\mathbf{C 8} \\
(\mathbf{5 5} \mathrm{kDa})\end{array}$ & 1 & 0,78 & 0,5 & 0,49 & 0,2 \\
\hline $\begin{array}{c}\mathbf{C 9} \\
(\mathbf{4 5} \mathrm{kDa})\end{array}$ & 1 & 1,18 & 1,06 & 0,85 & 0,81 \\
\hline $\begin{array}{c}\beta \text {-Actin } \\
(\mathbf{4 2} \text { kDa })\end{array}$ & 1 & 1 & 1,04 & 1.17 & 0,98 \\
\hline
\end{tabular}

Fig. 5 Caspase dependence of WQF 044. Control cells (Co) were left untreated or treated with DMSO. Comparison of data was calculated by a one-tail $t$ test. Results have been asterisked as followed: ${ }^{*} p<0.05 ; * * p<0.01 ; * * * p<0.001$. a After incubating Nalm6 cells for $48 \mathrm{~h}$ hours with different concentrations of WQF 044, the mitochondrial permeability transition was measured by flow cytometric analysis. Values are given as percentage of cells with low $\Delta \Psi_{\mathrm{m}} \pm \mathrm{SD}$ $(n=3)$. b BJAB cells were treated with $2 \mu \mathrm{M}$ and $3 \mu \mathrm{M}$ of WQF 044 , alone and in combination with the pancaspase-inhibitor zVAD-fmk $(\mathrm{ZV})$. As control $7.5 \mathrm{nM}$ of epirubicin (Epi) were pipetted alone and in combination with ZVAD-fmk. After $72 \mathrm{~h}$ of incubation at $37{ }^{\circ} \mathrm{C}$, DNA fragmentation was measured by flow cytometric analysis. Values were given in percentage of apoptotic cells $\pm \operatorname{SD}(n=3)$. Statistical comparison of data was between the single WQF 044 group and the combined treatment with $\mathrm{ZV}$, respectively. $\mathrm{c} \mathrm{BJAB}$ and 7CCA cells were incubated with different concentrations of WQF 044 for $72 \mathrm{~h}$. DNA fragmentation was measured by flow cytometric analysis.
Apoptotic cells were displayed as percentage of the means of three separate samples \pm SD. Doxorubicin (Doxo) was applied at $86 \mathrm{nM}$ to show the resistance. d MCF-7/mock cells were compared with MCF-7/casp-3 cells in their induction of apoptosis after incubating them with 10 and $20 \mu \mathrm{M}$ of WQF 044 for $72 \mathrm{~h}(n=3)$. As in the MelHO cells, higher concentrations than in Nalm6 and BJAB cells were used due to the lower sensitivity of these adherent cells. e WQF 044 induces caspase-8 (C8) and caspase-9 (C9) activation in Nalm6 cells. Daunorubicin (Dau) was used as positive control. Nalm6 cells were treated with $2 \mu \mathrm{M}$ and $3 \mu \mathrm{M}$ of WQF 044 . All cells were incubated for $48 \mathrm{~h}$ at $37^{\circ} \mathrm{C}$. The separation of $20 \mu \mathrm{g}$ cytosolic proteins was done by SDS-PAGE, followed by subjecting them to the western blot analysis. Immunblotting was then done with an anti-C8 and anti-C9 antibody. $43 \mathrm{kDa} \beta$-actin was detected to prove equal loading. The western blot quantification was calculated using GeneTools (Syngene). The control was set as 1. DMSO, Dau and WQF 0442 and $3 \mu \mathrm{M}$ were compared with the control, respectively 
protease. In these MCF-7/casp-3 cells, the DNA fragmentation grade increased from 34 percent at $10 \mu \mathrm{M}$ of WQF 044 to 81 percent at $20 \mu \mathrm{M}$ (Fig. 5d). In comparison, exposing MCF-7/mock cells to WQF 044 resulted in no induction of apoptosis. At $20 \mu \mathrm{M}$ of WQF 044 , less than 12 percent of the cells were apoptotic.

Our investigations of WQF 044 in caspase-3 over- and under-expressed cell lines were supported by using the pancaspase-inhibitor zVAD-fmk. The treatment of BJAB cells with WQF 044 and zVAD-fmk, alone and in combination, revealed an inactivation of the salalen ligand. WQF 044 could not induce apoptosis under the influence of the inhibitor in a dose-dependent manner (Fig. 5b). The apoptotic effects were significantly lower in the combination treatment with the inhibitor and $2 \mu \mathrm{M}$ of WQF 044 , and even very significantly reduced further when using $3 \mu \mathrm{M}$ of WQF 044 with zVAD-fmk. This result underlines the dependence of WQF 044 on the broad caspase-induced cell-death.

A western blot analysis, after treating Nalm6 cells with 2 and $3 \mu \mathrm{M}$ of WQF 044 for $48 \mathrm{~h}$, revealed smaller
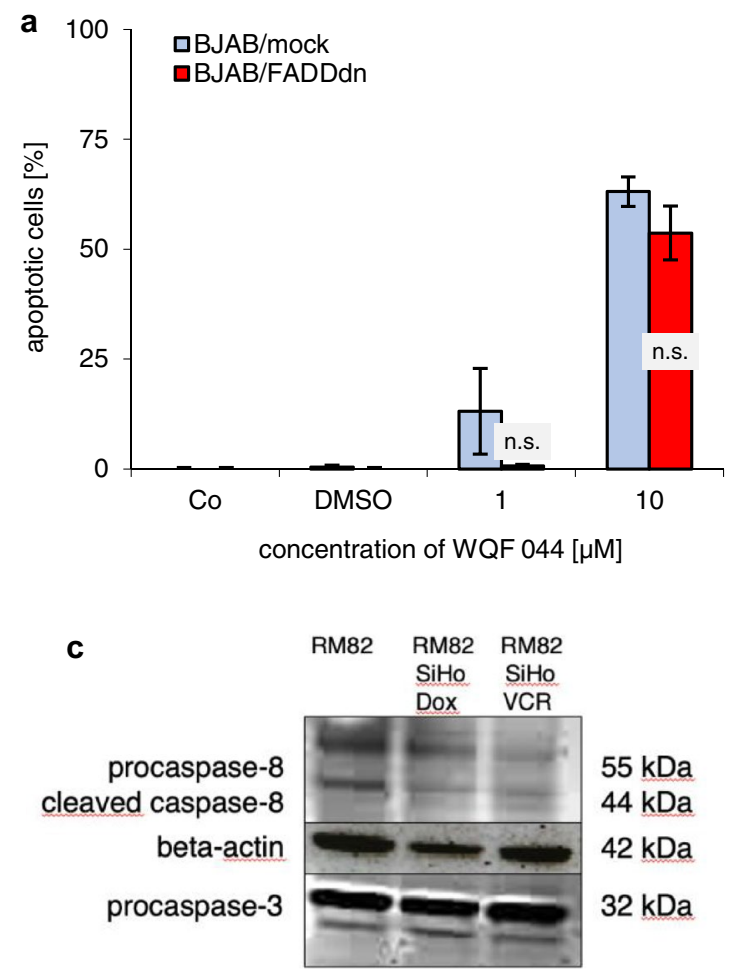

Fig. 6 Exclusion of the extrinsic apoptotic pathway. Incubation time for DNA fragmentation was $72 \mathrm{~h}$ at $37{ }^{\circ} \mathrm{C}$. It was measured by flow cytometric analysis. Values were given in percentage of apoptotic cells $\pm \mathrm{SD}(n=3)$. Control cells $(\mathrm{Co})$ were left untreated. a BJAB mock and BJAB/FADDdn cells were exposed with 1 and $10 \mu \mathrm{M}$ of WQF 044. The differences between the values of WQF 044-treated $\mathrm{BJAB} /$ mock and BJAB/FADDdn cells in the two concentrations were not significant (n.s.) with $p>0.05$. b RM82 and vincristine (VCR)resistant RM82SiHoVCR cells were treated with different concen- procaspase-9 $(49 \mathrm{kDa})$ and procaspase- $8(55 \mathrm{kDa})$ bands in the exposed cells compared to the control cells (Fig. 5e). The western blot quantification illustrated the lower number of proteins of inactivated caspase- 8 and caspase- 9 in comparison to the control cells. The processing of caspase- 9 underlined the activation of the mitochondrial pathway by WQF 044.

\section{WQF 044-induced apoptosis is independent of the extrinsic pathway}

Significant involvement of the extrinsic pathway, characterized by an activation of caspase- 8 , was excluded in different ways. BJAB/FADDdn cells were transfected with pcDNA3FADD-/-. They are expressing a dominant negative FADD mutant that is lacking the death domain. The BJAB/mock cells have a pcDNA3-Primer without the FADDdn gene. The values of WQF 044-treated apoptotic BJAB/FADDdn cells were not significantly higher than these in $\mathrm{BJAB} /$ mock cells (Fig. 6a).

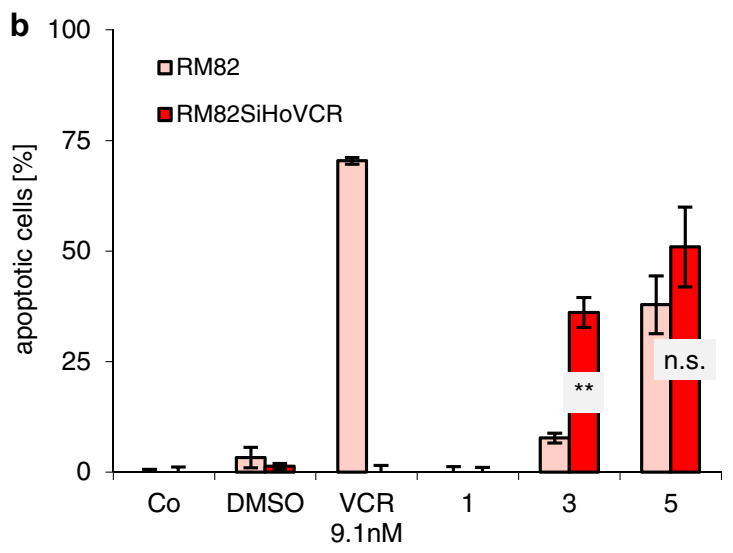

concentration of WQF $044[\mu \mathrm{M}]$

trations of WQF 044. Comparison of data was performed using a one-tail $t$ test. Results have been asterisked as $* * p<0.01$; $n s$ not significant. $\mathbf{c}$ Presence of caspase- 8 and -3 in untreated Ewing's sarcoma cells. For this paper, we focus on the RM82 and RM82SiHoVCR cell line. The separation of $20 \mu \mathrm{g}$ cytosolic proteins was done by SDSPAGE, followed by subjecting them to western blot analysis. Immunoblotting was then done with anti-caspase- 3 and anti-caspase- 8 antibodies. $42 \mathrm{kDa} \beta$-actin was detected to prove equal loading 
Superficially, an activation of caspase- 8 in the western blot analysis was inconsistent with the results of the BJAB/ FADDdn cells. However, a previous study demonstrated that caspase- 8 can be activated by caspase- 3 over the intrinsic pathway; hence its activation is independent of the CD95 death-inducing signaling complex (Wieder 2001).

These results were further supported by a DNA-fragmentation with a Ewing's sarcoma cell line from a primary tumor in the femur, called RM82, that we newly made resistant to vincristine (RM82SiHoVCR) (Ottaviano 2010; van Valen et al. 1992). Polymerase chain reactions and western blot analysis revealed a sixfold CD95-underexpression (data not shown) and a downregulation of procaspase-8 (Fig. 6c) in the vincristine-resistant RM82 cells, whereas caspase-3 bands did not distinguish between the primary tumor and the resistant cell line. Next to their vincristine-resistance, RM82SiHoVCR cells are resistant to several vinca alkaloids, anthracyclines (Table 1) and platins. CD95, also called Fas, is a pro-apoptotic member of the extrinsic pathway (Lavrik and Krammer 2012; Schmidt et al. 2015; Strasser et al. 2009). Thus, apoptosis of RM82SiHoVCR seems to be blocked over the extrinsic pathway. Van Valen et al. earlier described that wild-type RM82 cells can be affected by tumor necrosis factor-related apoptosis-inducing ligand (TRAIL), a member of the extrinsic pathway of apoptosis (Van Valen et al. 2000). Figure 4b clearly demonstrates that the induction of apoptosis by WQF 044 was not disrupted by the CD95-under-expression in vincristine-resistant Ewing's sarcoma cells. At a WQF 044 concentration of $3 \mu \mathrm{M}$, the value of apoptotic RM82SiHoVCR cells was even significantly higher than in regular RM82 cells.

\section{WQF 044 sensitizes BJAB cells to vincristine}

The use of polychemotherapy results in lower side effects of the selected cytostatic drugs during cancer treatment. Therefore, the compound WQF 044 was tested in combination with vincristine to see if it had the potential to sensitize BJAB cells. Vincristine is a main chemotherapeutic in the fight against Burkitt lymphoma (Dunleavy 2013; Painschab 2019). Thus, the cells were exposed separately to WQF 044 and vincristine and to a combination of both cytostatic agents. Very low concentrations were used that did not affect the cells in single use. The effects are shown in Fig. 7. Synergistic effects of 352 percent after combining $1 \mu \mathrm{M}$ of WQF 044 with $0.4 \mu \mathrm{M}$ of vincristine were observed. An even stronger synergism appeared after pipetting $1 \mu \mathrm{M}$ of WQF 044 plus $0.5 \mu \mathrm{M}$ of vincristine on BJAB cells ( 375 percent).

\section{WQF 044 is highly selective to tumor cells}

Remarkably, we found out that WQF 044 had nearly no apoptotic effect in healthy human leucocytes. We compared a DNA fragmentation of the substance in leucocytes with those in BJAB and Nalm6 cells. While the cancer cells were highly affected by WQF 044 in a dose-dependent manner, leucocytes showed no significant levels of apoptosis in WQF 044 concentrations from 1 to $5 \mu \mathrm{M}$ (Fig. 8a). As it turned out in the measurement of early/late apoptosis and necrosis, WQF 044 did not affect the leucocytes in a dose-dependent manner (Fig. 8b). At a WQF 044 concentration of $5 \mu \mathrm{M}$, less than 10 percent of the cells were either apoptotic or necrotic whereas the viability of the cells was at 92 percent (Figs. 2c, 8b).

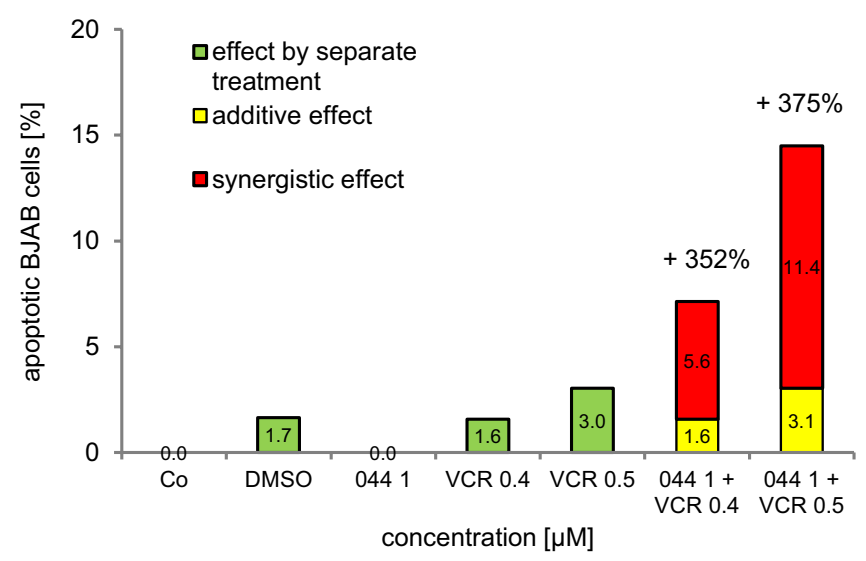

Fig. 7 Synergistic effects of WQF 044 (044) and vincristine (VCR). BJAB cells were treated with $1 \mu \mathrm{M}$ of WQF 044 and $0.4 / 0.5 \mu \mathrm{M}$ of vincristine, alone and in combination. Control cells $(\mathrm{Co})$ were left untreated or with DMSO. After $72 \mathrm{~h}$ of incubation at $37^{\circ} \mathrm{C}$, induc- tion of apoptosis was measured by flow cytometric analysis of nuclear DNA fragmentation. Values were given in percentage of apoptotic cells and were expressed at means $\pm \operatorname{SD}(n=3)$. To determine synergistic effects, the fractional product was calculated 


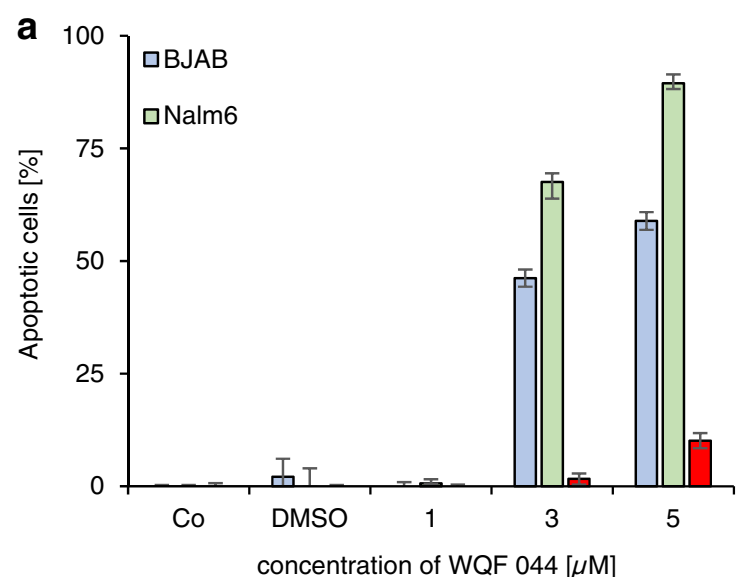

Fig. 8 Selectivity of WQF 044 to cancer cells. a A DNA fragmentation of treated BJAB, Nalm6 and non-malignant leucocytes was done. Cells were treated with 1 to $5 \mu \mathrm{M}$ of WQF 044 and incubated for $72 \mathrm{~h}$ at $37{ }^{\circ} \mathrm{C}$. The number of apoptotic cells was measured by flow cytometric analysis using three batches per concentration. Values were given in percentage and were expressed at means \pm SD. $\mathbf{b}$ After incu-

\section{Discussion}

The discovery of novel organic compounds is of high interest since the discovery of the high cytostatic metal complex cisplatin. Severe side effects such as nephrotoxicity, allergic reactions and gastrointestinal symptoms often limit chemotherapy with cisplatin (Dasari and Tchounwou 2014). Therefore, the metal-free salalen ligand WQF 044 might be a potential alternative with less toxicity.

Especially after long-term chemotherapy, MDR represents a huge problem that causes therapy failure (Baguley 2010). In clinical use, cytostatic agents that modulate ABC transporters have not always proven as efficient as they seemed during their laboratory investigations ( $\mathrm{Li} 2017$ ). Thus, finding new substances with the potential to overcome MDR is a very important goal in oncology research. The examination of the metal-free ligand WQF 044 revealed very promising characteristics of the substance as a future cytostatic drug. An impressive overcoming of MDR in daunorubicin- and vincristine-resistant Nalm6 cells was observed (Fig. 3a, b). The substance defeated the over-expression of $\mathrm{P}$-gp. Moreover, quite remarkable anti-proliferative effects of WQF 044 in leukemia cells were detected in a low micromolar range (Fig. 2b).

The synergetic effects of WQF 044 and vincristine in $\mathrm{BJAB}$ cells make the compound even more attractive as a substance that overcomes the defense barrier of the acute lymphoblastic leukemia and Burkitt-lymphoma that cannot be successfully treated with typical common therapies (Fig. 7).

Potential anti-cancer substances often fail in clinical use due to high toxicity. For example, colchicine was used in

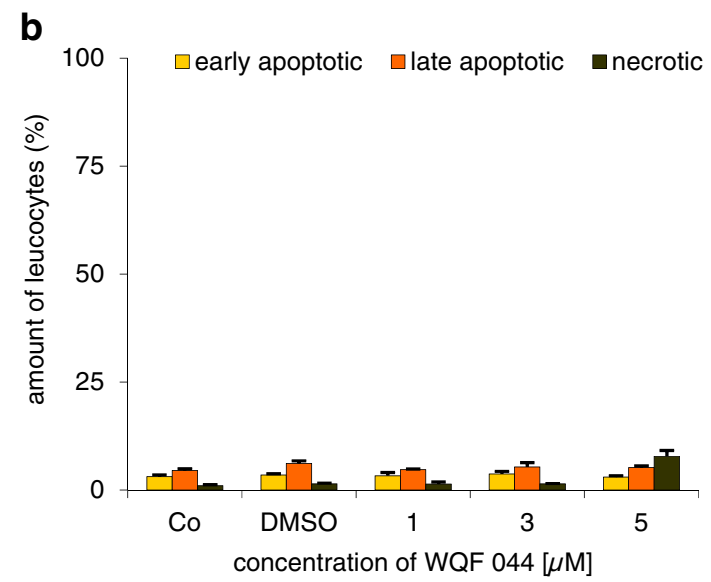

bation at $37{ }^{\circ} \mathrm{C}$ for $48 \mathrm{~h}$ with 1 to $5 \mu \mathrm{M}$ of WQF 044 , early and late apoptosis and necrosis were measured in leucocytes after Annexin V/ PI staining by using flow cytometry $(n=3)$. AnnV+/PI- cells were defined as early apoptotic, AnnV+/PI+ as late apoptotic and AnnV-/ $\mathrm{PI}+$ as necrotic cells

low concentrations to treat gout and familial Mediterranean fever, but the higher concentrations, that are necessary for anti-cancer treatment, resulted in too many side effects (Kumar et al. 2017). Furthermore, several metal complexes were very promising for anti-cancer treatment, but their in-vivo toxicity often limited their use (Liang et al. 2017). In contrast, the substance WQF 044 is a metal-free ligand, thus avoiding metal-induced toxicity. As a most exciting consequence, no apoptotic effects were seen upon treating the healthy human leucocytes with WQF 044, compared to the high apoptotic values in leukemia and lymphoma cells (Figs. 2c, 8a, b). In comparison, leukemia and lymphoma cells lost their viability and showed early and late apoptosis after treating them with WQF 044 (Fig. 2c-e).

Other metal ligands have already been tested in tumor cells. As mentioned in the introduction, the metal-free salantype compound THG 1213 has been examined and showed anti-proliferative and apoptotic effects in Nalm6 and solid tumor cells and their resistant cell lines in low micromolar concentrations. In contrast, the salen ligand THG 1212 did not affect tumor cells (Dragoun et al. 2018).

Next to the experiments that were done with THG 1213, we widened the examination of WQF 044 with several experiments. Due to our high interest in new metal complexes and their ligands, we focused on cells of a Ewing's sarcoma. The well-known platin derivate cisplatin is used in relapsed treatment of Ewing's sarcoma patients, but strong side effects limit their use (van Maldegem 2015). Therefore, the impressive apoptotic effects of WQF 044, even in resistant Ewing's sarcoma cells, are an important finding (Fig. 6b). The substance may be an alternative treatment in 
relapsed Ewing's sarcoma that still has a very frustrating survival-prognosis (Cotterill et al. 2000).

We further observed that the working mechanisms of WQF 044 and THG 1213 are different: THG 1213 could not affect the BJAB/FADDdn cells in the same way than regular $\mathrm{BJ} A \mathrm{~B}$ cells, underlining their dependence of the extrinsic pathway, whereas WQF 044 showed a clear independence of the extrinsic pathway of apoptosis as it was not dependent of CD95 (Fig. 6a) (Dragoun et al. 2018). CD95 (APO-1/Fas) is a death receptor and part of the death-including complex that activates caspase- 8 over the adapter molecule FADD (Krammer 2000). The independence of the WQF 044-induced apoptosis on the extrinsic pathway was supported by the results of the PCR array analysis: a sixfold under-expression of FADD and a 42-fold under-expression of CD95 were observed what is a clear point against the main involvement of the extrinsic pathway (Table 2).

Especially the fact that the salan THG 1213 induced apoptosis in a low micromolar range, but the salen THG 1212 did not affect the cells made the exploration of the corresponding salalen WQF 044 most interesting. The different results of THG 1213 and WQF 044 underline that even small differences in the chemical structure of a compound can cause completely different results in human cells. Earlier studies on other salans showed that these compounds developed anti-proliferative effects in MCF-7 and other human breast cancer cells at concentrations of 1-2 $\mu \mathrm{M}$ (Gao et al. 2007), whereas WQF 044 needed higher concentrations to affect MCF-7 cells. THG 1213 could not affect MCF-7 cells at all in this micromolar range (Dragoun et al. 2018). Future in-vivo experiments are intended to probe whether the metal-free ligands WQF 044 and THG 1213 show different efficiency on this level.

The examination of other substances illustrates that it cannot be predicted a priori whether a ligand or a metal complex cause better anti-cancer effects. For example, Kilic et al. (2018) found that different hemi-salen ligands showed higher anticancer activity in four different cancer cell lines, whereas related triboron complexes did not affect the cells in the same way (Kilic et al. 2018). Interestingly, Ghanbari (2014) observed that the increase in aromatic rings on the bridge between D-amino groups caused more apoptotic activity of their $\mathrm{Fe}(\mathrm{III})$-salen-like complexes (Ghanbari et al. 2014). Once again, both the ligand structure and the position of the substituent of the salen ligand can modify the effects on cancer cells.

In the case of the molybdenum complexes described by Dragoun et al. (2018), the complexes did not affect the tumor cells in the same way the ligands THG 1213 and WQF 044 did (Dragoun et al. 2018). In comparison to that, another study illustrated that a cobalt(III) salen complex had cytotoxic effects in BJAB and Nalm6 cells, but the corresponding ligand could not induce apoptosis in the tumor cells (Hopff et al. 2020). Furthermore, ruthenium(II) complexes had cytotoxicity effects in MCF-7 and human prostate tumor cells (DU-145) in a low micromolar range, whereas their metal-free-ligand did not provoke the same outcome (Correa 2016).

Due to its high anti-cancer potential, we were very interested in the mode of action of WQF 044 and found out that the intrinsic pathway played a main role. The mitochondrial membrane potential was reduced in WQF 044 influenced Nalm6 cells (Fig. 5a). The high permeability of the mitochondria membrane results in a release of cytochrome $\mathrm{c}$ into the cytosol (Kroemer and Reed 2000). This activates procaspase-9, among other proteins. The downstream caspases, especially caspase- 3 and caspase- 8 , are stimulated, so that they lead to DNA fragmentation and apoptosis (Hengartner 2000; Herr and Debatin 2001; Nagata 2000). The consumption of procaspase- 8 and procaspase- 9 after treating Nalm6 cells with WQF 044 was detected in the western blot analysis (Fig. 5e). The fact that caspase- 8 was activated by WQF 044, but the substance did not mainly act over the extrinsic pathway was explained by the phenomenon of a caspase-3 induced caspase- 8 activation as described (Wieder et al. 2001).

Furthermore, besides the blocking of P-gp, the compound acted caspase dependent. The extremely low apoptotic effects in caspase-3 under-expressed 7CCA and caspase-3 defective MCF-7/mock cells clearly illustrated that the protease is necessary for WQF 044 to develop its effects on the cells (Fig. 5c, d).

The strong inhibition of WQF 044-induced apoptotic effects by the pancaspase-inhibitor zVAD-fmk clearly supported the caspase-dependent apoptotic mechanism of the compound (Fig. 5b). The zVAD-fmk inhibitor did not completely block apoptosis in WQF 044 treated BJAB cells, whereas the positive control with epirubicin showed no apoptosis. This result points to the involvement of other members of the apoptotic pathway in the mechanism of action of the compound WQF 044.

A 43-fold over-expression of cytochrome $\mathrm{c}$ was detected in the PCR array analysis (Table 2). WQF 044 also overexpressed the direct IAP (inhibitor of apoptosis)-binding protein (DIABLO) by 15 -fold (Table 2). DIABLO is part of the intrinsic pathway as it is released from the mitochondria. It neutralizes the anti-apoptotic activity of IAP family members (Herr and Debatin 2001). The release of pro-apoptotic components like cytochrome $\mathrm{c}$ and DIABLO from the mitochondria is regulated by members of the Bcl-2 family. They influence apoptosis by changing the mitochondria membrane permeability (Antonsson and Martinou 2000; Liu and Hengartner 1999). We found that WQF 044 is dependent on the anti-apoptotic Bcl-2. The over-expression of Bcl-2 in $\mathrm{BiBo}$ and MelHO-Bcl2 cells reduced the apoptotic effects 
of WQF 044, underlining the involvement of the intrinsic pathway of apoptosis (Fig. 4a, b). Even though WQF 044 did not have the same apoptotic effects in BiBo cells compared to BJAB cells, it still induced apoptosis and overcame the Bcl-2 over-expression (Fig. 4a). This can be explained by the fact that WQF 044 inhibited Bcl-2, as the compound evoked an 18-fold under-expression of this anti-apoptotic protein (Table 2). However, WQF 044 did not break the over-expression of Bcl-2 by 30-fold, existing in the MelHO/ Bcl-2 cells, in a dose-dependent manner (Fig. 4b) (Onambele 2010). Another interesting observation was the fivefold over-expression of BAX in the PCR array analysis (Table 2). This is in line with the inhibition of the WQF 044-induced apoptotic effects when anti-apoptotic $\mathrm{Bcl}-2$ is predominant because then it inhibits BAX. Once activated, BAX directly supports the mitochondrial outer membrane permeabilization resulting in a release of killing effectors into the cytosol (Renault et al. 2013).

With our investigations of the salalen ligand WQF 044, we clearly detected the apoptotic mechanisms in different tumor cells and pointed out a main involvement of the intrinsic pathway of apoptosis. Next to the control of the intrinsic pathway of apoptosis by releasing proapoptotic factors, mitochondria own other functions to influence cell death (Orrenius et al. 2003). Therefore, the exact way of how a substance activates the mitochondrial mechanisms of apoptosis can differ. The metal ion reservoir can be depleted or the production of reactive oxygen species (ROS) can be increased above a cytotoxic threshold (Bao 2019; Nam et al. 2018; Yang et al. 2016). Further investigations in this direction are beyond the focus of this manuscript. It will surely to address these issues in future experiments.

\section{Conclusion}

Overall, our investigations revealed that salalen ligands, exemplified by compound WQF 044, are quite promising for anti-cancer treatment. Especially the low cytotoxic effects in healthy human leucocytes and the wide range of tumors, that WQF 044 can combat, make the substance highly interesting for future use as a chemotherapeutic. Additionally, we gained new insights into the in-vitro activity of this compound by underlining the mitochondrial function in cancer cells, resulting in a new approach to fight against resistant cancers, especially in childhood.

\section{Methods}

\section{Materials}

Rnase A was from Qiagen (Hilden, Germany). Propidium iodide $(50 \mu \mathrm{g} / \mathrm{ml})$ was from Serva (Heidelberg, Germany). Further the zVAD-fmk (pancaspase/ panprotease) inhibitor was used. All common cytostatics were provided by the Children's Hospital of the City Cologne, Amsterdamer Straße. The cytostatic agents were freshly dissolved as stock solutions in DMSO prior to the experiments. They were diluted with the respective cell culture media or buffer during the assay procedures. The substance WQF 044 was dissolved in a 40-mM stock solution of DMSO. Next to the regular control cells in the experiments, some cells were incubated with an equal amount of DMSO only, as DMSO control. The results showed similar effects to those obtained in the untreated controls.

WQF 044 was synthesized and characterized according to Berkessel et al. (2007).

\section{Cell lines and cell cultures}

We used the human $\mathrm{b}$ cell precursor leukemia cell line Nalm6 (AG Henze, Charité, Berlin), the Burkitt-like lymphoma BJAB/mock cells (Prof. Dr. S. Fulda, University of Ulm), the BJAB/FADDdn cells (Peter Daniel, Charité Berlin), the breast adenocarcinoma MCF-7/mock and MCF-7/ casp-3 cells (Prof. Dr. R. Jänicke, University of Düsseldorf) and the human melanoma MelHO pIRES and MelHO Bcl-2 cells (Dr. Eberle, Charité, Berlin). Nalm6 and BJAB cells were made resistant in our lab by exposing them to increasing concentrations of the current cytostatic drug. RM82 is a human Ewing's sarcoma cell line from F. Van Valen, University of Muenster, Germany that was exposed to increasing concentrations of vincristine to make the cells resistant (RM82SiHoVCR).

The cell lines were incubated in $250 \mathrm{ml}$ cell culture bottles at $37{ }^{\circ} \mathrm{C}$. RPMI 1640 medium (GIBCO, Invitrogen, Karlsruhe, Germany) was used for the suspension cells. Heat inactivated fetal calf serum (FCS, $10 \%$, v/v), L-glutamine $(0.56 \mathrm{~g} / \mathrm{l})$, penicillin $(100,000$ i.u. $)$ and streptomycin $(0.1 \mathrm{~g} / \mathrm{l})$ were added. The adherent cells were grown in DMEM supplemented with FCS $(10 \%$, v/v) and geniticine $(0.4 \mathrm{mg} / \mathrm{ml})$. We took care of the cell cultures twice a week and diluted them to a concentration of $1 \times 10^{5}$ cells $/ \mathrm{ml} .24 \mathrm{~h}$ before using the cells for experiments, they were adjusted to $3 \times 10^{5}$ cells $/ \mathrm{ml}$ to have standard conditions in growing. Immediately before the start of experiments, cells were diluted to $1 \times 10^{5}$ cells $/ \mathrm{ml}$. 


\section{Measuring the inhibition of cell proliferation by CASY cell counter and analyzer system}

CASY cell counter and analyzer system from Roche were used to determine cell count and viability with specifically defined settings for the current cell lines. The system measures the cell concentration in three different size ranges that include cell debris, dead cells and viable cells (Voisard et al. 1991). Before measuring, all cells were treated with different concentrations of WQF 044. Some cells were left untreated or with DMSO as control. Incubation time was $24 \mathrm{~h}$ at $37^{\circ} \mathrm{C}$. Then, cells were resuspended and $100 \mu \mathrm{l}$ of each well was diluted in $10 \mathrm{ml}$ of CASYton (ready-to-use isotonic saline solution) for an immediate automated count of the cells. We defined the control group of the cells as $100 \%$ growth meaning that a cell concentration not higher than at the beginning of the experiment reveals maximum inhibition of cell proliferation.

\section{LDH release assay for excluding necrosis}

To make sure that cell death was due to apoptosis and not necrosis, a measurement of the lactate dehydrogenase (LDH) release was made. Nalm6 cells were exposed to different concentrations of WQF 044 and incubated for $3 \mathrm{~h}$. With the help of the Cytotoxicity Detection Kit from Roche (Mannheim, Germany), the release of LDH out of the cells was measured in the cell culture supernatants. After centrifugation at $350 \mathrm{~g}$ for $5 \mathrm{~min}, 20 \mu \mathrm{l}$ of cell-free supernatants was diluted with $80 \mu \mathrm{l}$ phosphate-buffered saline (PBS) supplemented with $100 \mu \mathrm{l}$ reaction mixture containing 2-(4-iodophenyl)-3-(4-nitrophenyl)-5-phenyl-tetrazolium chloride (INT), sodium lactate, $\mathrm{NAD}^{+}$and diaphorase. Time-dependent formation of the reaction product was quantified photometrically at $490 \mathrm{~nm}$. The maximum amount of LDH release was determined after lysis of the cells using 0.1 percent Triton X-100 in culture medium and set to represent 100 percent cell death.

\section{Annexin V/propidium iodide binding assay}

The Annexin-V-Fluos Staining kit (Roche, Mannheim, Germany) was used to detect early and late apoptosis and necrosis. Nalm6 and BJAB cells and healthy human leucocytes were incubated with different concentrations of WQF 044 for $48 \mathrm{~h}$ at $37^{\circ} \mathrm{C}$. The preparation of the samples was made according to the instructions of the manufacturer. The data were analyzed by using the FACScan (Becton Dickinson, Heidelberg, Germany), equipped with the CELL Quest software. Early apoptosis was defined as Annexin V-positive and PI-negative and late apoptosis as Annexin V/PI-double-positive. Vital cells were Annexin V/PI-double-negative (Brauchle et al. 2014; Wlodkowic et al. 2011). Annexin
V-negative and PI-positive marked necrotic cells that were damaged during the isolation procedure (van Engeland et al. 1998).

\section{Measurement of DNA fragmentation}

For detecting the percentage of apoptotic cells, different concentrations of WQF 044 were pipetted on the cells before incubating them for $72 \mathrm{~h}$ at $37^{\circ} \mathrm{C}$. Then, adherent cells were washed with $180 \mu$ l Phosphate-buffered saline (PBS) and treated with trypsin for $5 \mathrm{~min}$ at $37^{\circ} \mathrm{C}$. A centrifugation at $1500 \mathrm{rpm}$ helped to collect all cells. Then, they were fixed in $200 \mu \mathrm{lBS} / 2 \%$ (v/v) formaldehyde on ice for $30 \mathrm{~min}$, continued by a centrifugation at $1500 \mathrm{rpm}$ for $5 \mathrm{~min}$ by $4{ }^{\circ} \mathrm{C}$. After incubating them with $180 \mu \mathrm{l}$ ethanol/PBS $(2: 1, \mathrm{v} / \mathrm{v})$ for $15 \mathrm{~min}$, followed by a 5 -min centrifugation at $1500 \mathrm{rpm}$, cells were resuspended in $50 \mu \mathrm{l} \mathrm{PBS}$ containing $40 \mu \mathrm{g} / \mathrm{ml}$ Rnase A that for $30 \mathrm{~min}$ at $37^{\circ} \mathrm{C}$. Cells were centrifuged at $1500 \mathrm{rpm}$ for $5 \mathrm{~min}$ for a last time; then they were finally resuspended in $200 \mu \mathrm{l}$ PBS containing $50 \mu \mathrm{g} / \mathrm{ml}$ propidium iodide. As described, the nuclear DNA fragmentation on the single cell level was measured by a modified cell cycle analysis (Essmann et al. 2000). By using a FACScan (Becton Dickinson, Heidelberg, Germany), equipped with the CELL Quest software, data were collected and analyzed. The results show the number of apoptotic cells reflected by the percentage of hypoploidy (subG1). In the end, the current apoptotic effects were calculated by subtracting the background apoptosis of the control cells from total apoptosis seen in the treated cells.

\section{Immunoblotting}

After $48 \mathrm{~h}$ of incubation with different concentrations of WQF 044, Nalm6 cells were washed twice with PBS and lysed in buffer containing $10 \mathrm{mM}$ Tris- $\mathrm{HCl}, \mathrm{pH} 7.5$, $300 \mathrm{mM} \mathrm{NaCl}, 1 \%$ Triton X-100, $2 \mathrm{mM} \mathrm{MgCl} 2,5 \mu \mathrm{M}$ ethylenediamino tetra-acetic acid (EDTA), $1 \mu \mathrm{M}$ pepstatin, $1 \mu \mathrm{M}$ leupeptin, and $0.1 \mathrm{mM}$ phenylmethyl-sulfonyl fluoride (PMSF). The same process was made with untreated RM82 and RM82SiHoVCR cells. By using the bicinchoninic acid assay from Pierce (Rockford, IL, USA), the protein concentration was determined and equal amounts of protein were separated by SDS-PAGE (Laemmli 1970; Smith 1985). The immunoblotting was performed as described (Wieder et al. 1994). The blocking of the membrane was made for $1 \mathrm{~h}$ in PBST (PBS, 0.05\% Tween-20) containing BSA and incubated with different primary antibodies for $1 \mathrm{~h}$. The anti-caspase-8, anti-caspase 9, anti-caspase-3, and antibeta-actin from Sigma, Saint Louis, USA were used. After washing of the membrane with PBST, secondary antibody (anti-mouse IgG HRP from Bioscience, San Diego, USA and anti-rabbit IgG HRP from Promega, Minneapolis, USA) in 
PBST was applied for $1 \mathrm{~h}$. After washing, the protein bands were detected using the ECL enhanced chemiluminescence system (Amersham Buchler, Braunschweig, Germany). The western blot quantification was done using GeneTools (Syngene).

\section{Measurement of the mitochondrial permeability transition}

Nalm6 cells were treated with different concentrations of WQF 044 and incubated for $48 \mathrm{~h}$ at $37^{\circ} \mathrm{C}$. The cells were then centrifuged at $1500 \mathrm{rpm}, 4{ }^{\circ} \mathrm{C}$ for $5 \mathrm{~min}$. The JC- 1 dye (5,5',6,6'-tetrachloro-1,1',3,3'-te-traethyl-benzimidazolylcarbocyanin io-dide, Molecular Probes, Leiden, The Netherlands) was used on the cells to determine the mitochondrial permeability transition as described (Lambert et al. 1989; Reers et al. 1995). Most of the cells were resuspended in $500 \mu \mathrm{l}$ phenol red free RPMI 1640 without supplements, and $\mathrm{JC}-1$ was added to give a final concentration of $2,5 \mu \mathrm{g} /$ $\mu \mathrm{l}$. Control cells were left without JC-1. Thus, all cells were incubated for $30 \mathrm{~min}$ at $37^{\circ} \mathrm{C}$ and moderately shaken. To collect the cells again, they were centrifuged at $1500 \mathrm{rpm}$ for 5 min at $4{ }^{\circ} \mathrm{C}$. $200 \mu \mathrm{l}$ ice-cold PBS was used to wash cells. The flow cytometric determination of cells with decreased fluorescence was used to measure the mitochondrial permeability transition. The FACScan (Becton Dickinson, Heidelberg, Germany) was equipped with the CELL Quest software and analyzed the samples. Control cells with low $\Delta \Psi_{\mathrm{m}}$ were subtracted from the values observed in the treated cells. Data are given in percentage of cells with low $\Delta \Psi_{\mathrm{m}}$, which reflects the number of cells undergoing mitochondrial apoptosis.

\section{Gene expression analysis}

The differential expression of multiple genes involved in the different apoptosis pathways was analyzed by using the apoptosis specific RT2 profiler (polymerase chain reaction) PCR expression arrays (SuperArray PAHS-012Z; SABiosciences Corporation, Frederick, MD, USA), according to the manufacturer's instructions (Inohara et al. 1997). Nalm6 cells were incubated with $1 \mu \mathrm{M}$ of WQF 044 for 16 h, RM82 and RM82SiHoVCR cells were left untreated. Then total RNA was extracted from the cells. RNAs were treated with Dnase I (2 U/ $\mu$ l) to eliminate possible genomic DNA contamination. The total RNA (700 ng/ $\mu$ l) was used as a template for the synthesis of a cDNA probe. It was then subjected to quantitative real-time PCR SuperArray analysis according to the manufacturer's instructions using a LightCycler480 (Roche Diagnostics). The hybridization signals were normalized by the means of nine housekeeping genes. The results were analyzed by using the SuperArray Analyzer Software. Data are given as x-fold expression of the respective genes as compared with control (untreated Nalm6 or RM82 cells) cells incubated in vehicle-containing medium for $16 \mathrm{~h}$.

\section{Isolation of healthy human leucocytes}

$10 \mathrm{ml}$ RPMI 1640 medium was added to $50 \mathrm{ml}$ blood of a healthy test person. Then, $4 \mathrm{ml}$ of Ficoll (SaccharoseEpichlorhydrin-Copolymer) was pipetted in a 15-ml tube, followed by carefully adding $5 \mathrm{ml}$ blood on the top. After $18 \mathrm{~min}$ of centrifugation at $657 \mathrm{~g}\left(20^{\circ} \mathrm{C}\right)$, the leucocytes were collected by slowly transferring them with a Pasteur pipette into a $45-\mathrm{ml}$ tube. $20 \mathrm{ml}$ of RPMI 1640 was added. This solution was centrifuged at $1500 \mathrm{rpm}$ for $5 \mathrm{~min}$. The cell count and viability were determined by CASY cell counter and analyzer system from Roche. Cells were seeded at a density of $3 \times 10^{5}$ cells $/ \mathrm{ml}$. The following steps are identical to those in the measurement of DNA fragmentation as described above.

\section{Statistical analysis}

Statistically significant values were compared using a onetailed $t$ test. $p$ values were expressed with asterisk. $p<0.05$ $(*)$ was considered statistically significant, $p<0.01(* *)$ highly significant and $p<0.001(* * *)$ extremely significant. If $p>0.05$ is calculated, the result is not significant (n.s.).

Acknowledgements We thank the Dr. Kleist Stiftung Berlin, and the Fonds der Chemischen Industrie for their general support.

Author contributions All authors contributed to the study conception and design. Material preparation, data collection and analysis was performed by SMH. CF, MA, NW and NW supported the data collection for the testing of multidrug resistances of selected cell lines. The first draft of the manuscript was written by SMH and all authors commented on previous versions of the manuscript. All authors read and approved the final manuscript.

Funding Open Access funding enabled and organized by Projekt DEAL.

\section{Declarations}

Conflict of interest The authors declare that they have no conflict of interest.

Ethical approval This article does not contain any studies with human participants or animals performed by any of the authors.

Open Access This article is licensed under a Creative Commons Attribution 4.0 International License, which permits use, sharing, adaptation, distribution and reproduction in any medium or format, as long as you give appropriate credit to the original author(s) and the source, provide a link to the Creative Commons licence, and indicate if changes were made. The images or other third party material in this article are 
included in the article's Creative Commons licence, unless indicated otherwise in a credit line to the material. If material is not included in the article's Creative Commons licence and your intended use is not permitted by statutory regulation or exceeds the permitted use, you will need to obtain permission directly from the copyright holder. To view a copy of this licence, visit http://creativecommons.org/licenses/by/4.0/.

\section{References}

Antonsson B, Martinou JC (2000) The Bcl-2 protein family. Exp Cell Res 256:50-57. https://doi.org/10.1006/excr.2000.4839

Baguley BC (2010) Multidrug resistance in cancer methods. Mol Biol 596:1-14. https://doi.org/10.1007/978-1-60761-416-6_1

Bao L et al (2019) The human transient receptor potential melastatin 2 ion channel modulates ROS through Nrf2. Sci Rep 9:14132. https://doi.org/10.1038/s41598-019-50661-8

Berkessel A, Brandenburg M, Leitterstorf E, Frey J, Lex J, Schafer M (2007) A practical and versatile access to dihydrosalen (Salalen) ligands: highly enantioselective titanium in situ catalysts for asymmetric epoxidation with aqueous hydrogen peroxide. Adv Synth Catal 349:2385-2391. https://doi.org/10.1002/adsc.20070 0221

Brauchle E, Thude S, Brucker SY, Schenke-Layland K (2014) Cell death stages in single apoptotic and necrotic cells monitored by raman microspectroscopy. Sci Rep 4:4698. https://doi.org/10. 1038/srep04698

Bruijnincx PC, Sadler PJ (2008) New trends for metal complexes with anticancer activity. Curr Opin Chem Biol 12:197-206. https://doi. org/10.1016/j.cbpa.2007.11.013

Cohen GM (1997) Caspases: the executioners of apoptosis. Biochem J 326(1):1-16

Correa RS et al (2016) Ruthenium(II) complexes of 1,3-thiazolidine2-thione: cytotoxicity against tumor cells and anti-trypanosoma cruzi activity enhanced upon combination with benznidazole. J Inorg Biochem 156:153-163. https://doi.org/10.1016/j.jinorgbio. 2015.12.024

Cotterill SJ, Ahrens S, Paulussen M, Jurgens HF, Voute PA, Gadner H, Craft AW (2000) Prognostic factors in Ewing's tumor of bone: analysis of 975 patients from the European intergroup cooperative Ewing's sarcoma study group. J Clin Oncol 18:3108-3114. https://doi.org/10.1200/JCO.2000.18.17.3108

Dasari S, Tchounwou PB (2014) Cisplatin in cancer therapy: molecular mechanisms of action. Eur J Pharmacol 740:364-378. https://doi. org/10.1016/j.ejphar.2014.07.025

Dragoun M, Gunther T, Frias C, Berkessel A, Prokop A (2018) Metalfree salan-type compound induces apoptosis and overcomes multidrug resistance in leukemic and lymphoma cells in vitro. J Cancer Res Clin Oncol 144:685-695. https://doi.org/10.1007/ s00432-018-2592-x

Dunleavy K et al (2013) Low-intensity therapy in adults with Burkitt's lymphoma. N Engl J Med 369:1915-1925. https://doi.org/10. 1056/NEJMoa1308392

Edlich F (2018) BCL-2 proteins and apoptosis: recent insights and unknowns. Biochem Biophys Res Commun 500:26-34. https:// doi.org/10.1016/j.bbrc.2017.06.190

Engels IH, Totzke G, Fischer U, Schulze-Osthoff K, Janicke RU (2005) Caspase-10 sensitizes breast carcinoma cells to TRAIL-induced but not tumor necrosis factor-induced apoptosis in a caspase3-dependent manner. Mol Cell Biol 25:2808-2818. https://doi. org/10.1128/MCB.25.7.2808-2818.2005

Essmann F, Wieder T, Otto A, Muller EC, Dorken B, Daniel PT (2000) GDP dissociation inhibitor D4-GDI (Rho-GDI 2), but not the homologous rho-GDI 1, is cleaved by caspase- 3 during druginduced apoptosis. Biochem J 346(Pt 3):777-783

Fadok VA, Xue D, Henson P (2001) If phosphatidylserine is the death knell, a new phosphatidylserine-specific receptor is the bellringer. Cell Death Differ 8:582-587. https://doi.org/10.1038/sj.cdd.44008 56

Gao J, Liu YG, Zhou Y, Zingaro RA (2007) Chiral salicyl diamines: potent anticancer molecules. ChemMedChem 2:1723-1729. https://doi.org/10.1002/cmdc.200700049

Garner TP, Lopez A, Reyna DE, Spitz AZ, Gavathiotis E (2017) Progress in targeting the BCL-2 family of proteins. Curr Opin Chem Biol 39:133-142. https://doi.org/10.1016/j.cbpa.2017.06.014

Ghanbari Z et al (2014) Structure-activity relationship for Fe(III)salen-like complexes as potent anticancer agents. Sci World J 2014:745649. https://doi.org/10.1155/2014/745649

Gottesman MM, Pastan I (1988) The multidrug transporter, a doubleedged sword. J Biol Chem 263:12163-12166

Gottesman MM, Fojo T, Bates SE (2002) Multidrug resistance in cancer: role of ATP-dependent transporters. Nat Rev Cancer 2:48-58. https://doi.org/10.1038/nrc706

Grutzke M, Zhao T, Immel TA, Huhn T (2015) Heptacoordinate heteroleptic salan (ONNO) and thiosalan (OSSO) titanium(IV) complexes: investigation of stability and cytotoxicity. Inorg Chem 54:6697-6706. https://doi.org/10.1021/acs.inorgchem.5b00690

Hengartner MO (2000) The biochemistry of apoptosis. Nature 407:770-776. https://doi.org/10.1038/35037710

Herr I, Debatin KM (2001) Cellular stress response and apoptosis in cancer therapy. Blood 98:2603-2614

Hopff SM, Onambele LA, Brandenburg M, Berkessel A, Prokop A (2020) Discovery of a cobalt (III) salen complex that induces apoptosis in Burkitt like lymphoma and leukemia cells, overcoming multidrug resistance in vitro. Bioorg Chem 104:104193. https://doi.org/10.1016/j.bioorg.2020.104193

Immel TA, Groth U, Huhn T, Ohlschlager P (2011) Titanium salan complexes displays strong antitumor properties in vitro and in vivo in mice. PLoS ONE 6:e17869. https://doi.org/10.1371/ journal.pone.0017869

Immel TA, Grutzke M, Batroff E, Groth U, Huhn T (2012a) Cytotoxic dinuclear titanium-salan complexes: structural and biological characterization. J Inorg Biochem 106:68-75. https://doi.org/10. 1016/j.jinorgbio.2011.08.029

Immel TA, Grutzke M, Spate AK, Groth U, Ohlschlager P, Huhn T (2012b) Synthesis and X-ray structure analysis of a heptacoordinate titanium(IV)-bis-chelate with enhanced in vivo antitumor efficacy. Chem Commun (camb) 48:5790-5792. https://doi.org/ $10.1039 / \mathrm{c} 2 \mathrm{cc} 31624 \mathrm{~b}$

Inohara N, Ding L, Chen S, Nunez G (1997) harakiri, a novel regulator of cell death, encodes a protein that activates apoptosis and interacts selectively with survival-promoting proteins Bcl-2 and Bcl-X(L). EMBO J 16:1686-1694. https://doi.org/10.1093/emboj/ 16.7.1686

Jesse P, Mottke G, Eberle J, Seifert G, Henze G, Prokop A (2009) Apoptosis-inducing activity of Helleborus niger in ALL and AML. Pediatr Blood Cancer 52:464-469. https://doi.org/10.1002/ pbc. 21905

Kater B, Hunold A, Schmalz HG, Kater L, Bonitzki B, Jesse P, Prokop A (2011) Iron containing anti-tumoral agents: unexpected apoptosis-inducing activity of a ferrocene amino acid derivative. J Cancer Res Clin Oncol 137:639-649. https://doi.org/10.1007/ s00432-010-0924-6

Kater L et al (2012) The role of the intrinsic FAS pathway in titanocene Y apoptosis: the mechanism of overcoming multiple drug resistance in malignant leukemia cells. Toxicol in Vitro 26:119-124. https://doi.org/10.1016/j.tiv.2011.09.010

Kelland L (2007) The resurgence of platinum-based cancer chemotherapy. Nat Rev Cancer 7:573-584. https://doi.org/10.1038/nrc2167 
Kilic A, Koyuncu I, Durgun M, Ozaslan I, Kaya IH, Gonel A (2018) Synthesis and characterization of the hemi-salen ligands and their triboron complexes: spectroscopy and examination of anticancer properties. Chem Biodivers. https://doi.org/10.1002/cbdv.20170 0428

Krammer PH (2000) CD95's deadly mission in the immune system. Nature 407:789-795. https://doi.org/10.1038/35037728

Krishna R, Mayer LD (2000) Multidrug resistance (MDR) in cancer. Mechanisms, reversal using modulators of MDR and the role of MDR modulators in influencing the pharmacokinetics of anticancer drugs. Eur J Pharm Sci 11:265-283

Kroemer G, Reed JC (2000) Mitochondrial control of cell death. Nat Med 6:513-519. https://doi.org/10.1038/74994

Kumar A, Sharma PR, Mondhe DM (2017) Potential anticancer role of colchicine-based derivatives: an overview. Anticancer Drugs 28:250-262. https://doi.org/10.1097/CAD.0000000000000464

Laemmli UK (1970) Cleavage of structural proteins during the assembly of the head of bacteriophage T4. Nature 227:680-685

Lambert IH, Hoffmann EK, Jorgensen F (1989) Membrane potential, anion and cation conductances in Ehrlich ascites tumor cells. J Membr Biol 111:113-131

Lavrik IN, Krammer PH (2012) Regulation of CD95/Fas signaling at the DISC cell. Death Differ 19:36-41. https://doi.org/10.1038/ cdd.2011.155

Lee SY et al (2010) [NiII(3-OMe-salophene)]: a potent agent with antitumor activity. J Med Chem 53:6064-6070. https://doi.org/ $10.1021 / \mathrm{jm} 100459 \mathrm{k}$

Lee SY et al (2011) [Fe(III)(salophene)Cl], a potent iron salophene complex overcomes multiple drug resistance in lymphoma and leukemia cells. Leuk Res 35:387-393. https://doi.org/10.1016/j. leukres.2010.11.007

Li YJ et al (2017) Autophagy and multidrug resistance in cancer. Chin J Cancer 36:52. https://doi.org/10.1186/s40880-017-0219-2

Liang JX, Zhong HJ, Yang G, Vellaisamy K, Ma DL, Leung CH (2017) Recent development of transition metal complexes with in vivo antitumor activity. J Inorg Biochem 177:276-286. https://doi.org/ 10.1016/j.jinorgbio.2017.06.002

Lin JH, Yamazaki M (2003) Role of P-glycoprotein in pharmacokinetics: clinical implications. Clin Pharmacokinet 42:59-98. https:// doi.org/10.2165/00003088-200342010-00003

Liu QA, Hengartner MO (1999) The molecular mechanism of programmed cell death in C elegans. Ann N Y Acad Sci 887:92-104

Marques MB et al (2019) Modeling drug-drug interactions of AZD1208 with vincristine and daunorubicin on ligand-extrusion binding TMD-domains of multidrug resistance P-glycoprotein (ABCB1). Toxicology 411:81-92. https://doi.org/10.1016/j.tox. 2018.10.009

Meker S, Manna CM, Peri D, Tshuva EY (2011) Major impact of $N$-methylation on cytotoxicity and hydrolysis of salan Ti(IV) complexes: sterics and electronics are intertwined. Dalton Trans 40:9802-9809. https://doi.org/10.1039/c1dt11108f

Mir JM, Jain N, Jaget PS, Maurya RC (2017) Density functionalized $[\mathrm{Ru}(\mathrm{II})(\mathrm{NO})(\mathrm{Salen})(\mathrm{Cl})]$ complex: computational photodynamics and in vitro anticancer facets. Photodiagnosis Photodyn Ther 19:363-374. https://doi.org/10.1016/j.pdpdt.2017.07.006

Mukhametov A, Raevsky OA (2017) On the mechanism of substrate/ non-substrate recognition by P-glycoprotein. J Mol Graph Model 71:227-232. https://doi.org/10.1016/j.jmgm.2016.12.008

Nagata S (2000) Apoptotic DNA fragmentation. Exp Cell Res 256:1218. https://doi.org/10.1006/excr.2000.4834

Nair P, Lu M, Petersen S, Ashkenazi A (2014) Apoptosis initiation through the cell-extrinsic pathway. Methods Enzymol 544:99128. https://doi.org/10.1016/B978-0-12-417158-9.00005-4

Nam E, Han J, Suh JM, Yi Y, Lim MH (2018) Link of impaired metal ion homeostasis to mitochondrial dysfunction in neurons. Curr
Opin Chem Biol 43:8-14. https://doi.org/10.1016/j.cbpa.2017. 09.009

Onambele LA et al (2010) Mitochondrial mode of action of a thymidine-based cisplatin analogue breaks resistance in cancer cells. Chemistry 16:14498-14505. https://doi.org/10.1002/chem.20100 0785

Orrenius S, Zhivotovsky B, Nicotera P (2003) Regulation of cell death: the calcium-apoptosis link. Nat Rev Mol Cell Biol 4:552-565. https://doi.org/10.1038/nrm1150

Ottaviano L et al (2010) Molecular characterization of commonly used cell lines for bone tumor research: a trans-European EuroBoNet effort. Genes Chromosom Cancer 49:40-51. https://doi.org/10. $1002 /$ gcc. 20717

Painschab MS et al (2019) Prospective study of burkitt lymphoma treatment in adolescents and adults in malawi. Blood Adv 3:612-620. https://doi.org/10.1182/bloodadvances.2018029199

Peri D, Meker S, Manna CM, Tshuva EY (2011) Different ortho and para electronic effects on hydrolysis and cytotoxicity of diamino bis(phenolato) "salan" Ti(IV) complexes. Inorg Chem 50:1030 1038. https://doi.org/10.1021/ic101693v

Pieters R, Klumper E, Kaspers GJ, Veerman AJ (1997) Everything you always wanted to know about cellular drug resistance in childhood acute lymphoblastic leukemia. Crit Rev Oncol Hematol 25:11-26

Rabik CA, Dolan ME (2007) Molecular mechanisms of resistance and toxicity associated with platinating agents. Cancer Treat Rev 33:9-23. https://doi.org/10.1016/j.ctrv.2006.09.006

Reers M, Smiley ST, Mottola-Hartshorn C, Chen A, Lin M, Chen LB (1995) Mitochondrial membrane potential monitored by JC-1 dye. Methods Enzymol 260:406-417

Renault TT, Teijido O, Antonsson B, Dejean LM, Manon S (2013) Regulation of bax mitochondrial localization by Bcl-2 and Bcl$\mathrm{x}(\mathrm{L})$ : keep your friends close but your enemies closer. Int J Biochem Cell Biol 45:64-67. https://doi.org/10.1016/j.biocel.2012. 09.022

Rubbiani R et al (2010) Benzimidazol-2-ylidene gold(I) complexes are thioredoxin reductase inhibitors with multiple antitumor properties. J Med Chem 53:8608-8618. https://doi.org/10.1021/ jm100801e

Schlegel RA, Williamson P (2001) Phosphatidylserine, a death knell. Cell Death Differ 8:551-563. https://doi.org/10.1038/sj.cdd. 4400817

Schmidt JH, Pietkiewicz S, Naumann M, Lavrik IN (2015) Quantification of CD95-induced apoptosis and NF-kappaB activation at the single cell level. J Immunol Methods 423:12-17. https:// doi.org/10.1016/j.jim.2015.04.026

Smith PK et al (1985) Measurement of protein using bicinchoninic acid. Anal Biochem 150:76-85

Strasser A, Jost PJ, Nagata S (2009) The many roles of FAS receptor signaling in the immune system. Immunity 30:180-192. https:// doi.org/10.1016/j.immuni.2009.01.001

Terenzi A et al (2016) Another step toward DNA selective targeting: $\mathrm{Ni}(\mathrm{II})$ and $\mathrm{Cu}$ (II) complexes of a Schiff base ligand able to bind gene promoter G-quadruplexes. Dalton Trans 45:7758-7767. https://doi.org/10.1039/c6dt00648e

Uderzo C, Conter V, Dini G, Locatelli F, Miniero R, Tamaro P (2001) Treatment of childhood acute lymphoblastic leukemia after the first relapse: curative strategies. Haematologica 86:1-7

Van Cruchten S, Van Den Broeck W (2002) Morphological and biochemical aspects of apoptosis, oncosis and necrosis. Anat Histol Embryol 31:214-223

van Engeland M, Nieland LJ, Ramaekers FC, Schutte B, Reutelingsperger CP (1998) Annexin V-affinity assay: a review on an apoptosis detection system based on phosphatidylserine exposure. Cytometry 31:1-9. https://doi.org/10.1002/(sici)10970320(19980101)31:1\%3c1::aid-cyto1\%3e3.0.co;2-r 
van Maldegem AM et al (2015) Etoposide and carbo-or cisplatin combination therapy in refractory or relapsed Ewing sarcoma: a large retrospective study. Pediatr Blood Cancer 62:40-44. https://doi.org/10.1002/pbc.25230

van Valen F, Winkelmann W, Jurgens H (1992) Expression of functional Y1 receptors for neuropeptide Y in human Ewing's sarcoma cell lines. J Cancer Res Clin Oncol 118:529-536. https:// doi.org/10.1007/bf01225268

Van Valen F et al. (2000) Apoptotic responsiveness of the Ewing's sarcoma family of tumours to tumour necrosis factor-related apoptosis-inducing ligand (TRAIL). Int J Cancer 88:252-259. doi: https://doi.org/10.1002/1097-0215(20001015)88:2<252:: aid-ijc $17>3.0 . c 0 ; 2-\mathrm{u}$

Voisard R, Dartsch PC, Seitzer U, Roth D, Kochs M, Hombach V (1991) Cell culture as a prescreening system for drug prevention of restenosis? Vasa 33:140-141

Wang Y, Cui J, Dai Y, Wu Y, Huang W, Qian H, Ge L (2017) Reversal of P-glycoprotein-mediated multidrug resistance and pharmacokinetics study in rats by WYX-5. Can J Physiol Pharmacol 95:580-585. https://doi.org/10.1139/cjpp-2016-0518

Wieder T, Geilen CC, Wieprecht M, Becker A, Orfanos CE (1994) Identification of a putative membrane-interacting domain of CTP:phosphocholine cytidylyltransferase from rat liver. FEBS Lett 345:207-210

Wieder T, Orfanos CE, Geilen CC (1998) Induction of ceramidemediated apoptosis by the anticancer phospholipid analog, hexadecylphosphocholine. J Biol Chem 273:11025-11031
Wieder T et al (2001) Activation of caspase-8 in drug-induced apoptosis of B-lymphoid cells is independent of CD95/Fas receptorligand interaction and occurs downstream of caspase-3. Blood 97:1378-1387

Wild A et al (2012) Synthesis of a glycopolymeric Pt(II) carrier and its induction of apoptosis in resistant cancer cells. Chem Commun (camb). https://doi.org/10.1039/c2cc31275a

Wlodkowic D, Telford W, Skommer J, Darzynkiewicz Z (2011) Apoptosis and beyond: cytometry in studies of programmed cell death. Methods Cell Biol 103:55-98. https://doi.org/10. 1016/B978-0-12-385493-3.00004-8

Won JH et al (2018) 23-Hydroxyursolic acid isolated from the stem bark of cussonia bancoensis induces apoptosis through fas/caspase-8-dependent pathway in HL-60 human promyelocytic leukemia cells. Molecules. https://doi.org/10.3390/molecules23123306

Yang Y, Karakhanova S, Hartwig W, D'Haese JG, Philippov PP, Werner J, Bazhin AV (2016) Mitochondria and mitochondrial ROS in cancer: novel targets for anticancer therapy. J Cell Physiol 231:2570-2581. https://doi.org/10.1002/jcp.25349

Publisher's Note Springer Nature remains neutral with regard to jurisdictional claims in published maps and institutional affiliations. 